\title{
Progress of Catalytic Valorization of Bio-Glycerol with Urea into Glycerol Carbonate as a Monomer for Polymeric Materials
}

\author{
Heng Zhang $\mathbb{D}^{1,2}$, Hu Li $\mathbb{D}^{1},{ }^{1}$ Anping Wang $\mathbb{D}^{1},{ }^{1}$ Chunbao (Charles) Xu $\mathbb{D D}^{2}$ and Song Yang $\mathbb{D}^{1}$ \\ ${ }^{1}$ State Key Laboratory Breeding Base of Green Pesticide \& Agricultural Bioengineering, \\ Key Laboratory of Green Pesticide \& Agricultural Bioengineering, Ministry of Education, \\ State-Local Joint Laboratory for Comprehensive Utilization of Biomass, Center for Research \& Development of Fine Chemicals, \\ Guizhou University, Guiyang, Guizhou 550025, China \\ ${ }^{2}$ Institute for Chemicals and Fuels from Alternative Resources (ICFAR), Department of Chemical and Biochemical Engineering, \\ Western University, London, Ontario N6A 5B9, Canada
}

Correspondence should be addressed to Hu Li; hli13@gzu.edu.cn, Chunbao (Charles) Xu; cxu6@uwo.ca, and Song Yang; jhzx.msm@gmail.com

Received 8 August 2019; Accepted 20 November 2019; Published 29 January 2020

Academic Editor: Leonard D. Tijing

Copyright (c) 2020 Heng Zhang et al. This is an open access article distributed under the Creative Commons Attribution License, which permits unrestricted use, distribution, and reproduction in any medium, provided the original work is properly cited.

\begin{abstract}
Versatile polymers with highly adjustable characteristics and a broad range of applications are possibly developed owing to the contemporary industrial polymerization techniques. However, industrial production of large amounts of chemicals and polymers heavily depends on petroleum resources which are dwindling and unsustainable. Of particular interest is to utilize sustainable and green resources for the manufacture of polymeric materials. The efficient transformation of bio-glycerol to the relevant functional derivatives are being widely investigated owing to the increasing demand for enhancing the value of glycerol manufactured by biodiesel and oleochemical industries. With respect to glycerol-based polymer chemistry and technology, considering the economy and environmental benefits, using effective catalysts for the selective transformation of bio-glycerol and urea into glycerol carbonate (GC) as a polymer monomer is of great significance. In this review, recent studies on GC synthesis involving the catalysts such as zinc, magnesium, tungsten, ionic liquid-based catalysts, reaction conditions, and possible pathways are primarily described. Some critical issues and challenges with respect to the rational development of heterogeneous catalytic materials like well-balanced acidbase sites are also illustrated.
\end{abstract}

\section{Introduction}

Modern life depends on polymers, from materials applied in the manufacture of clothing, houses, cars, and airplanes to those demonstrating complex adhibitions in medicine, diagnostics, and electronics [1-4]. A vast majority of polymers have been contributing greatly to our better daily life of enhanced quality and cleaner living environments, for instance, as materials capable of purifying water or as polymers bearing the better fuel economy in aerospace utilizations. Nonetheless, most of these polymers are supplied by the traditional petrochemicals. It is reported that merely $6 \%$ of the oils furnished globally are used to produce polymers, but the raw resources and their end-of-life options will arouse the important environmental issues [5]. Since there is no panacea for these sophisticated environmental concerns, one alternative is to exploit more "sustainable" polymers. Research has been focusing basically on developing the renewable feedstocks to substitute fossil raw sources and on opening-up the end-of-life options that can provide materials that are feasible in recycling or biodegradation $[6,7]$. As polymers are derived from sustainable biomass resources, they are generally deemed to be bioderived. It should be recognized that with respect to the concept of biodegradation, some petrochemical-derived polymers are also biodegradable, while some bioderived polymers will not biodegrade [8]. Generally, two procedures are used to prepare sustainable polymers: decreasing the environmental influence of traditional manufacture, such as by employing biomass materials for the manufacture of known monomers or polymers like polyethylene terephthalate and polyethylene; and preparing the novel, and "sustainable" structures like polylactide from renewable resources that are applied 


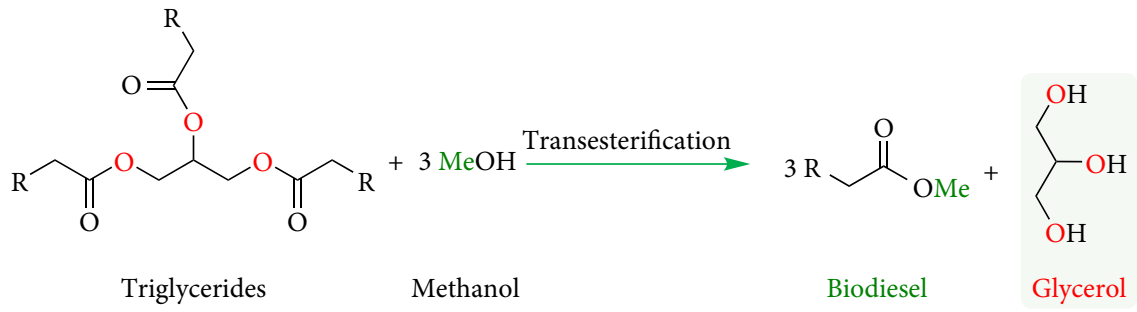

SCHeme 1: Catalytic transesterification of triglycerides to biodiesel and glycerol.

increasingly for preparing polymers $[9,10]$. Specifically, the vital monomers including carbon dioxide, terpenes, vegetable oils, and carbohydrates are being applied in manufacturing various sustainable materials and products, such as elastomers, plastics, hydrogels, flexible electronics, resins, engineering polymers, and composites [11, 12]. There are large opportunities to apply such sustainable polymers for the manufacture of both high-value fuels and chemicals, and for basic applications like packaging. It is worth noting that effective catalysis is usually demanded to generate monomers, to facilitate selective polymerizations and to enable recycling or upcycling of waste materials [13-15].

The increasing demands of biofuels and fuel additives, among which biodiesel has caused a considerable surplus of glycerol to the market that will create new threats in terms of their sustainable exploitation [16-19]. Stoichiometrically (Scheme 1), for the transesterification of triglycerides with methanol into biodiesel and glycerol, each tonne of biodiesel along with $100 \mathrm{~kg}$ of by-product crude glycerol are simultaneously generated $[20,21]$. It is important to recognize that the surplus of glycerol will not only arouse the serious disposal issues but also bring about the negative impact on the economy of the biodiesel industry. Therefore, with respect to the biodiesel process, the demand to use such a glycerol fraction by an economical approach is highly desirable [22-25]. A vast majority of means for the incorporation of by-product glycerol into the various branches of industry usually require costly and complicated purification courses. Among the possibilities, glycerol related polymer chemistry and technology has been bringing about increasing concerns because of the diversity of polymer constitutions and architectures available. This branch of industry is one of the largest glycerol consumers after food, pharmaceutical, and personal care applications sectors, and possibly the largest branch with no requirement of complex purification of glycerol during the biodiesel manufacture process $[26,27]$.

Glycerol carbonate (4-hydroxymethyl-2-oxo-1,3-dioxolane, GC), a very versatile chemical compound, is a colorless protic polar liquid having the merits of nontoxic, low evaporation rate, low flammability, and high boiling point $[28,29]$. It is of great industrial interest to develop the novel approaches to produce GC from glycerol since GC demonstrates the large potential ability in numerous applications, such as reactive protic solvent, surfactants, and pharmaceuticals. More importantly, GC can also serve as the vital building block to prepare polymers, such as polycarbonates, polyglycerol esters, hyperbranched polyols, and nonisocyanate polyurethanes [30,31].

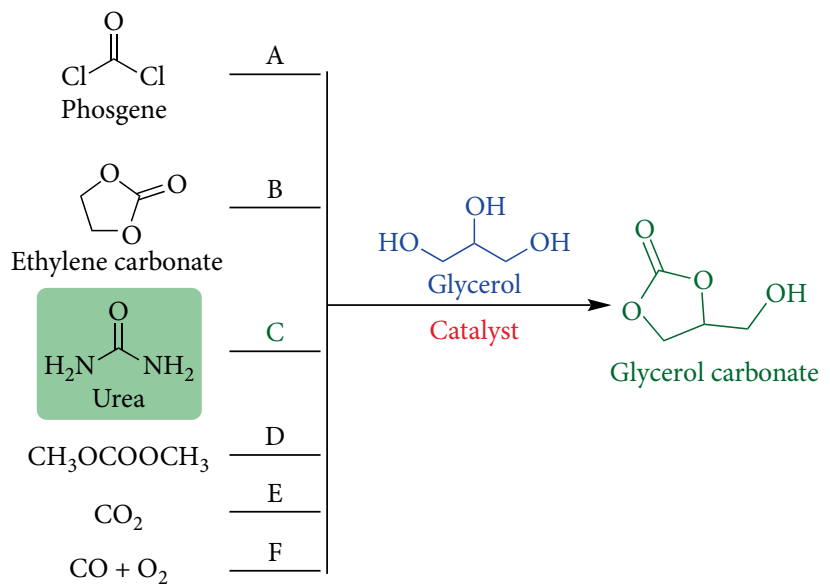

SCHEMe 2: Synthetic routes to glycerol carbonate.

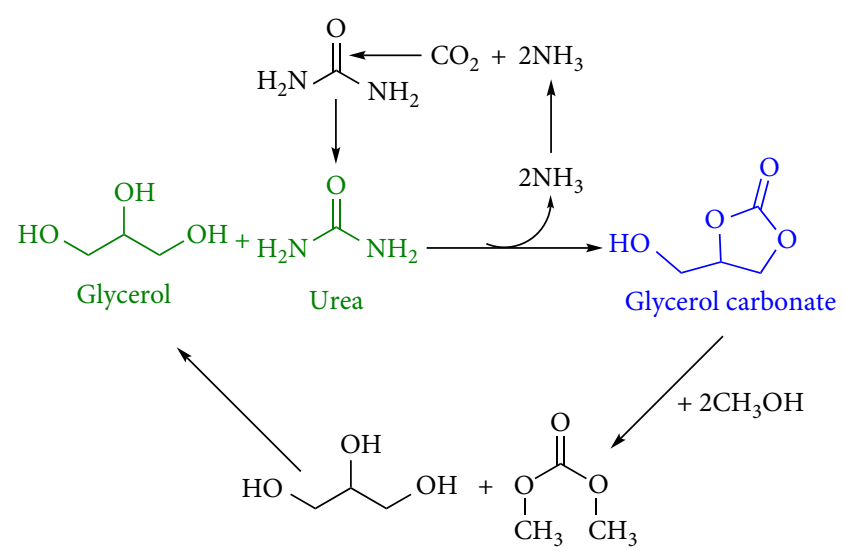

SCHEME 3: The glycerolysis of glycerol with urea into glycerol carbonate.

Thus far, some promising manners have been reported for GC manufacture from glycerol, as depicted in Scheme 2: (A) the reaction of glycerol with phosgene; (B) the transesterification of dialkyl carbonates with glycerol; (C) the glycerolysis of urea; (D) the transesterification of ethylene carbonate with glycerol; (E) the direct carboxylation with $\mathrm{CO}_{2}$; and $(\mathrm{F})$ the oxidative carbonylation of glycerol with $\mathrm{CO}$ and $\mathrm{O}_{2}[32,33]$. Nonetheless, upon using ethylene carbonate, GC will be hard to acquire since the by-product ethylene glycol is very difficult to be separated. Moreover, the important environmentally friendly issues should also be considered because the carcinogenic, 


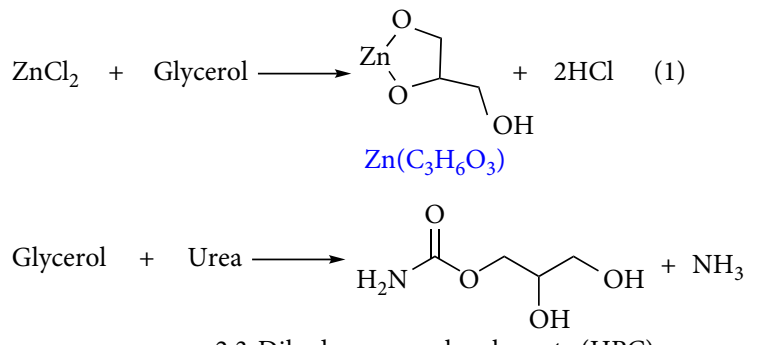

2,3-Dihydroxypropyl carbamate (HPC)

$\mathrm{ZnCl}_{2}+2 \mathrm{NH}_{3} \longrightarrow \mathrm{Zn}\left(\mathrm{NH}_{3}\right)_{2} \mathrm{Cl}_{2} \stackrel{\text { Glycerol }}{\longrightarrow} \mathrm{Zn}\left(\mathrm{C}_{3} \mathrm{H}_{6} \mathrm{O}_{3}\right)+2 \mathrm{NH}_{4} \mathrm{Cl}$

(a)

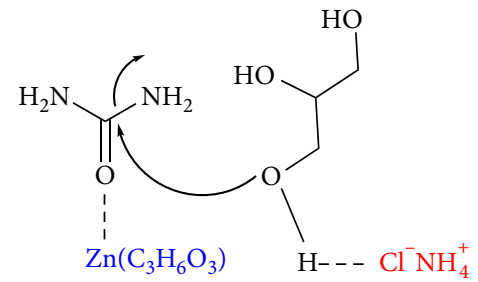

(b)

Scheme 4: (a) Reaction routes for the synthesis of $\mathrm{Zn}\left(\mathrm{C}_{3} \mathrm{H}_{6} \mathrm{O}_{3}\right)$; (b) Activation of urea and glycerol by $\mathrm{Zn}\left(\mathrm{C}_{3} \mathrm{H}_{6} \mathrm{O}_{3}\right)$ and $\mathrm{NH}_{4} \mathrm{Cl}$, respectively.

acutely toxic, and highly flammable substance, oxirane is utilized to prepare ethylene carbonate $[34,35]$. Considering the sustainable development, the application of toxic reagents including asphosgene or $\mathrm{CO}$ to make GC is also certainly not preferable [36]. In addition, some other attempts to synthesize GC directly using glycerol and $\mathrm{CO}_{2}$ under a supercritical reaction condition usually exhibit the low product yields (i.e., zeolites, $8 \%$ yield) [37]. Satisfactorily, in comparison with the methods mentioned above, the glycerolysis of urea can be deemed as a relatively green process to produce GC. The main advantages of glycerolysis of urea are that both glycerol and urea are readily available, cheap, and nontoxic, and this simple procedure can be conducted without using any solvent along with the high selectivity and GC yield under mild reaction conditions $[38,39]$. It is noteworthy that the GC production from glycerol and urea is currently drawing a mass of attention from a sustainable chemistry perspective: (a) utilizing and reducing the undesirable $\mathrm{CO}_{2}$ via the chemical transformation, (b) using the biodiesel by-product glycerol, and (c) producing a value-added chemical GC with versatile practical applications $[40,41]$. More importantly, as illustrated in Scheme 3, urea is an easily available and cheap substrate, while the coproduct ammonia, can be cycled back into urea manufacture, rendering the protocol quite atom economical [42].

Therefore, this review is dedicated to the state-of-the-art accomplishments made in the efficient transformation of bio-glycerol and urea into GC. The emphasis would be given to the catalytic performance of the relevant catalysts such as zinc, magnesium, tungsten, ionic liquid-based catalysts, and waste-derived materials, reaction conditions, and possible pathways. In addition, how to modify the reaction conditions that will influence the related activities and selectivity to GC is also depicted.

\section{Catalysts for Glycerol Carbonate Synthesis from Glycerol and Urea}

2.1. Reaction with Zinc-Based Catalyst. As depicted in Table 1, zinc-based catalysts demonstrate a lot of important results for GC synthesis. Zinc-catalyzed (homogeneous $\mathrm{ZnCl}_{2}$, $\mathrm{ZnBr}_{2}, \mathrm{ZnI}_{2}, \mathrm{ZnF}_{2}, \mathrm{Zn}\left(\mathrm{NO}_{3}\right)_{2} \cdot 6 \mathrm{H}_{2} \mathrm{O}$, and $\left.\mathrm{Zn}(\mathrm{OAc})_{2} \cdot 2 \mathrm{H}_{2} \mathrm{O}\right)$ synthesis of $\mathrm{GC}$ using glycerol and urea as substrates, was systematically evaluated with medium to excellent GC yields. Of the zinc-based catalysts measured, $\mathrm{ZnCl}_{2}$ demonstrated the highest catalytic activity, giving a high GC yield of $80.2 \%$ with $99.7 \%$ selectivity at $150^{\circ} \mathrm{C}$ in $2 \mathrm{~h}$ along with the urea/glycerol and $\mathrm{ZnCl}_{2} /$ glycerol molar ratios of 1 and 0.02 , respectively [43]. As shown in Scheme 4(a), according to the spectroscopic and elemental analyses, $\mathrm{Zn}\left(\mathrm{NH}_{3}\right) \mathrm{Cl}_{2}$ was produced firstly by the reaction of $\mathrm{ZnCl}_{2}$ with $\mathrm{NH}_{3}$, followed by reacting with glycerol to transform into zinc glycerolate, $\mathrm{Zn}\left(\mathrm{C}_{3} \mathrm{H}_{6} \mathrm{O}_{3}\right)$, and $\mathrm{NH}_{4} \mathrm{Cl}$. However, the catalytic performance of the sole $\mathrm{Zn}\left(\mathrm{C}_{3} \mathrm{H}_{6} \mathrm{O}_{3}\right)$ was determined to be considerably inferior to that of $\mathrm{ZnCl}_{2}$. Upon combining the employment of $\mathrm{NH}_{4} \mathrm{Cl}$, the activity could be greatly enhanced, indicating that the key catalytic active sites for glycerolysis of glycerol with urea were $\mathrm{Zn}\left(\mathrm{C}_{3} \mathrm{H}_{6} \mathrm{O}_{3}\right)$ and $\mathrm{NH}_{4} \mathrm{Cl}$ together. As depicted in Scheme 4(b), $\mathrm{NH}_{4} \mathrm{Cl}$ functioned to activate glycerol whereas $\mathrm{Zn}\left(\mathrm{C}_{3} \mathrm{H}_{6} \mathrm{O}_{3}\right)$ played the role in activating urea.

The homogeneous catalysts, polymeric glycerolate complexes of zinc (ZMG) and cobalt (CMG) containing a coordinated isocyanate ligand were successfully developed for the production of GC form the mixtures of glycerol and urea [44]. By analyzing the parameters of reaction temperature, time, and glycerol to urea molar ratios, the optimized reaction conditions for achieving a high GC yield of $83 \%$ were $5 \mathrm{wt} \% \mathrm{ZMG}$ catalyst dosage referred to glycerol at $140^{\circ} \mathrm{C}$ for $7 \mathrm{~h}$, and glycerol to urea molar ratio of $1: 1.5$. More importantly, as illustrated in Scheme 5, the proposed reaction mechanism shows that the polymeric glycerolate structure firstly breaks down by the reaction with urea, affording the vital intermediate complex involving a coordinated isocyanate complex. Then, the rearrangement of intermediate isocyanate ligand would generate a carbamate derivative which in turn could reversibly be replaced through cyclizing glycerol into GC. Meanwhile, this would also regenerate the metal monoglycerolate catalyst and the release of ammonia gas under vacuum conditions, accordingly.

By a coprecipitation manner at room temperature, zinc-aluminum hydrotalcite-like composite $\left(\mathrm{Zn}-\mathrm{Al}-\mathrm{SO}_{4}\right)$, comprising sulfate anion with a molar ratio of 3 , was developed and employed for preparing GC in one-pot [45]. To determinate the optimal parameters, the effects of reaction temperature, time, the molar ratio of glycerol to urea, and dosage of catalyst were investigated in detail. It was found that the synthesis of 


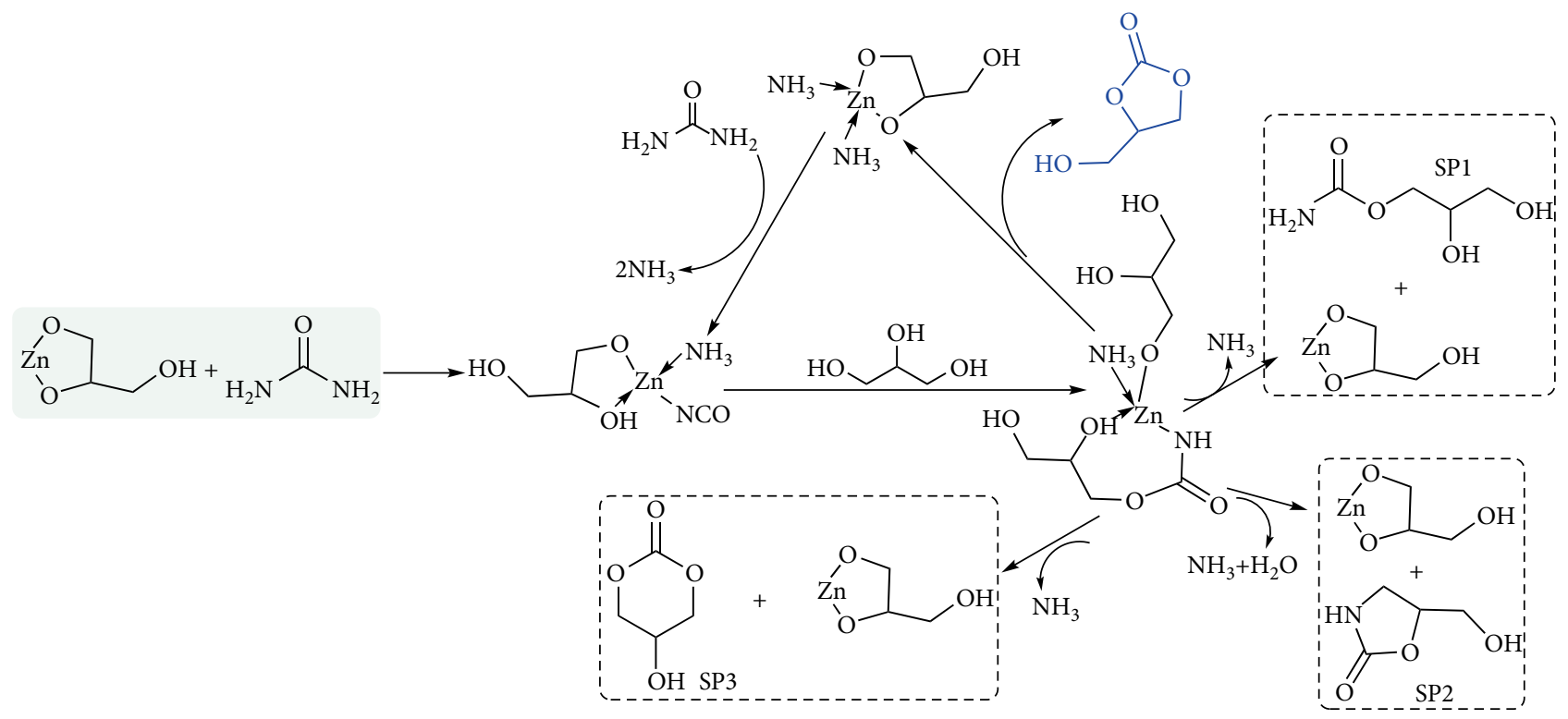

SCHEME 5: Reaction mechanism of glycerolysis of glycerol and urea using ZMG catalyst.

GC could be better conducted using the heterogeneous catalysts bearing an appropriate acidity. Accordingly, the maximum GC yield (92.8\%) was determined at $140^{\circ} \mathrm{C}$ for $4 \mathrm{~h}$ using the $\mathrm{Zn}-\mathrm{Al}-\mathrm{SO}_{4}$ catalysts with an amount ratio of $3.5 \mathrm{wt} \%$, and $5 \mathrm{wt} \%$ stoichiometric excess of urea. Furthermore, the as-prepared catalytic material was found to be insoluble in both the reactants and GC product, wherein enables $\mathrm{Zn}-\mathrm{Al}-\mathrm{SO}_{4}$ catalysts to substitute the difficult commercial $\mathrm{ZnO}$ or $\mathrm{ZnSO}_{4}$ catalysts of nonreusable property, to some extent. Interestingly, by deeply investigating the $\mathrm{Zn}$-containing solid catalysts (zinc oxide, smectite, hydrotalcite) along with several inorganic zinc salts for GC synthesis from glycerol and urea proceeded under solvent-free reaction conditions at $130^{\circ} \mathrm{C}$, the homogeneous but not heterogeneous catalytic behavior was discovered [46]. The constituent $\mathrm{Zn}$ species was found to be dissolved into the liquid phase even for the solid catalysts because of the action of both glycerol and urea, and the GC yield was determined to be correlated with the amount of zinc species leached into the liquid phase with a single relationship. As depicted in Scheme 6, based on the consequences of the reactions carried out under different reaction conditions and the detection of the liquid phase after the reaction by Fourier transform infrared spectroscopy (FT-IR), the possibly active $\mathrm{Zn}$ species were determined to be a complex of a $\mathrm{Zn}$ atom coordinated with $\mathrm{N}=\mathrm{C}=\mathrm{O}$. In fact, derived from this study, the dissolved $\mathrm{Zn}$ species were the active sites for the glycerolysis of glycerol and urea, which have the same structure irrespective of the parent solid catalysts employed.

To further develop the environmentally friendly catalytic protocols for GC synthesis from glycerol and urea, heterogeneous catalysts of environmental value synthesized by an important preparation stratagem should be considered first and foremost. Motivated by the residue-free and solvent-free synthetic manner that can fabricate the hierarchical nanoscaled catalyst dispersed on microparticles [47-51], the hierarchical nano-scaled $\mathrm{Co}_{3} \mathrm{O}_{4} / \mathrm{ZnO}$ composites wherein $\mathrm{CoO}$
(40-50 $\mathrm{nm}$ ) were hierarchically dispersed on the $\mathrm{ZnO}$ microscale particles $(0.2-1 \mu \mathrm{m})$ were synthesized by a very fast, easy and eco-friendly (no solvent, no surfactant, no residue) dry nanodispersion procedure. Importantly, this room-temperature-prepared material could bring about a clear interaction between $\mathrm{Co}_{3} \mathrm{O}_{4}$ and $\mathrm{ZnO}$ oxides, endowing an excellent catalytic activity (69\% conversion and close to $100 \%$ selectivity) in the transformation of sustainable resources as the glycerolysis of glycerol with urea at mild condition $\left(140^{\circ} \mathrm{C}\right.$ for $4 \mathrm{~h}$ ) [52]. More importantly, Raman spectroscopy evidenced the essence of the interphase oxides reaction whereas the formation of the spinel phase, $\mathrm{ZnCo}_{2} \mathrm{O}_{4}$, upon thermal treated at a high temperature of $400^{\circ} \mathrm{C}$ was the active species. A novel porous $\mathrm{ZnO}$ was manufactured by the calcination method using $\mathrm{Zn}$ glycerolate platelets as raw materials which were derived from a glycerol approach, and was used for GC production via glycerol carbonylation with urea [53]. Interestingly, the as-prepared catalyst displayed a porous and irregular morphology along with a proper acid-base property, thus affording the highest GC yield of $85.97 \%$ under the optimized reaction conditions of $5.0 \mathrm{wt} \%$ catalyst amount, 1:1.5 molar ratio of glycerol to urea at $140^{\circ} \mathrm{C}$ within $6 \mathrm{~h}$. Interestingly, in contrast to [46], the porous $\mathrm{ZnO}$ was also found to maintain its original catalytic performance during 5 recycles, indicating its active, recyclable, and environmentally friendly nature in industrial settings. $\mathrm{Zn}-\mathrm{Al}$ mixed oxides were synthesized through the coprecipitation or the hydrothermal manner and were employed for GC production by glycerolysis of glycerol with urea [54]. According to the physicochemical property investigated, the coprecipitation-prepared $\mathrm{Zn}$-Al mixed-oxides exhibited the better catalytic performance for GC synthesis than that of the hydrothermal-prepared ones. However, Shin et al. made three important contributions to $\mathrm{ZnAl}$ mixed oxides used in synthesizing GC from glycerol and urea, especially focusing on the detailed structure-function relationships [55-57]. $\mathrm{ZnO}$ and $\mathrm{ZnAl}$ mixed oxides ( $\mathrm{ZnAlO}$ ) were 


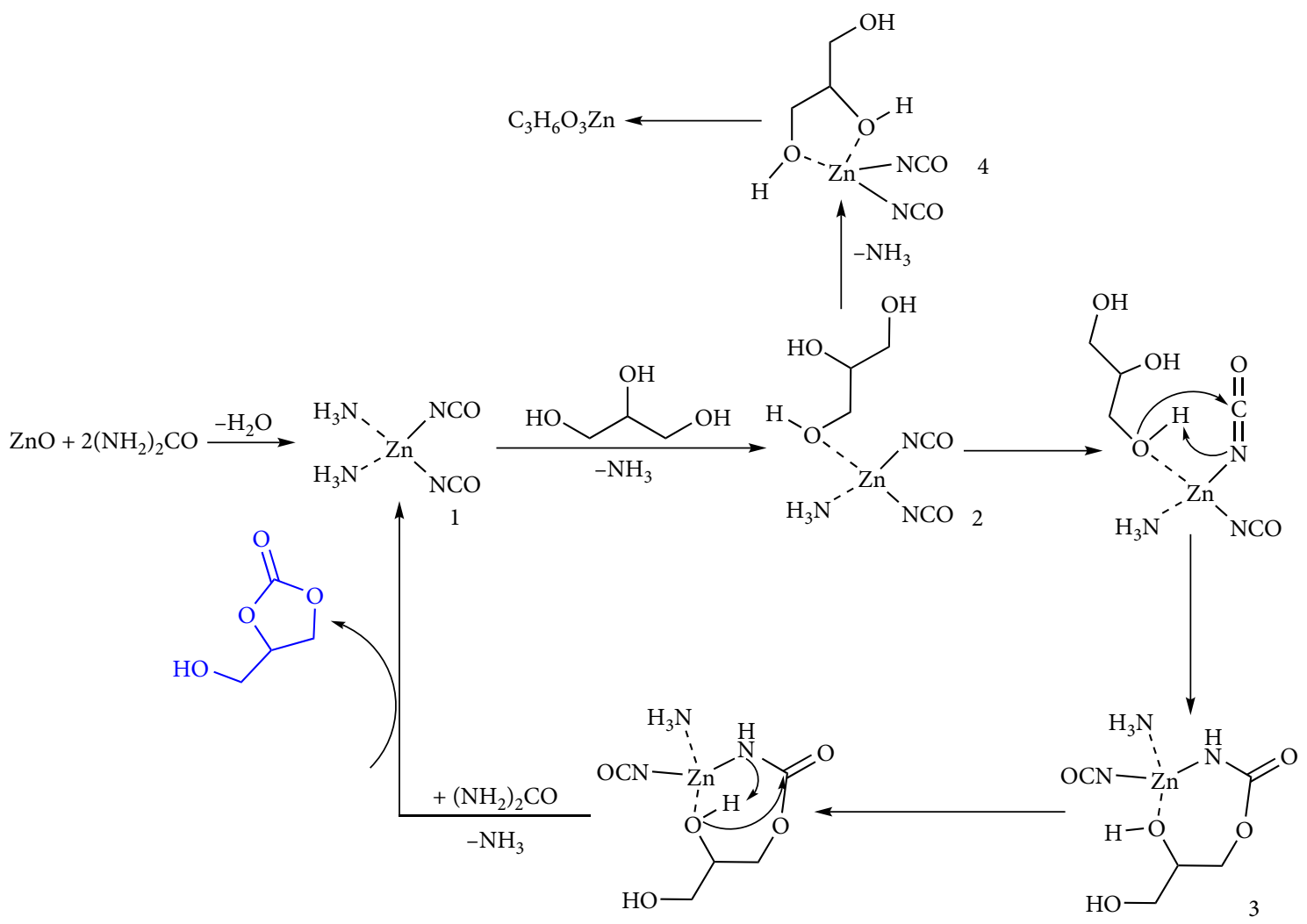

Scheme 6: The possible reaction mechanism for GC synthesis from glycerol and urea using Zn-containing catalyst.

developed and used in glycerol carbonylation with urea, aiming to investigate the $\mathrm{Zn}$-phase-dependent catalysis in detail [56]. It was found that the $\mathrm{ZnAlO}$ catalyst showed higher selectivity and yield of GC than those of $\mathrm{ZnO}$ catalyst. In detail, due to the reaction between $\mathrm{Zn}$ NCO complex and glycerol, the formed zinc glycerolate (ZnGly) in the solid phase lowered the GC selectivity accordingly. Alternatively, by using the $\mathrm{ZnAlO}$ catalyst, the $\mathrm{Zn}$ isocyanate (NCO) complexes formed were dominant up to $2 \mathrm{~h}$ in both liquid and solid phases. For recent research, they continued to investigate the effect of the disordered $\mathrm{ZnAl}_{2} \mathrm{O}_{4}$ spinel structure on GC production from glycerol and urea using pure $\mathrm{ZnAl}_{2} \mathrm{O}_{4}$ (c- $\mathrm{ZnAl}_{2} \mathrm{O}_{4}$ ), $\mathrm{ZnAl}$ mixed oxides (c- $\mathrm{ZnAlO}$ ) synthesized by a citrate complex manner, and $\mathrm{ZnAl}$ physically mixed oxides (p-ZnAlO) [57]. As demonstrated in detail in Scheme 7, the disordered bulk $\mathrm{ZnAl}_{2} \mathrm{O}_{4}$ phase could generate the disordered sites on the catalysts surface: $\mathrm{Zn}^{2+}$ cations were substituted by $\mathrm{Al}^{3+}$ cations at the tetrahedral sites, and the surface oxygen vacancy corresponding to the $\mathrm{Zn}^{2+}$ cations substituting for $\mathrm{Al}^{3+}$ cations at the octahedral sites. Accordingly, the disordered sites of $\mathrm{AlO}_{4}$ and oxygen vacancy of the partially inversed $\mathrm{ZnAl}_{2} \mathrm{O}_{4}$ spinel structure produced high surface acidity for $\mathrm{c}-\mathrm{ZnAlO}$ and $\mathrm{c}-\mathrm{ZnAl}_{2} \mathrm{O}_{4}$. $\mathrm{c}-\mathrm{ZnAlO}$ showed the best catalytic activity because of the higher ability to absorb the liquid $\mathrm{Zn}$ NCO complexes. Based on these reports, the solid Zn NCO complex was determined to primarily generate GC, whereas the liquid Zn NCO complex generated both GC and ZnGly.

It is worth mentioning that the acid-base nature of heterogeneous catalytic materials and their surface areas play a decisive role in GC production efficiency $[58,59]$. With respect to this, the novel zinc-tin composite oxide was prepared using three different means including coprecipitation, solid-state, and evaporation methods, and investigated in producing GC [60]. According to the relevant characterization techniques, three components of $\mathrm{Zn}_{2} \mathrm{SnO}_{4}, \mathrm{ZnO}$, and $\mathrm{SnO}_{2}$ were determined as the main composite oxides. Upon testing in the selective transformation of glycerol and urea into GC, $\mathrm{Zn}$-Sn mixed oxides synthesized by the coprecipitation manner ( $\mathrm{ZnSn}$-CoPre) performed better when compared to the others. Basically, the superior excellent catalytic performance of $\mathrm{ZnSn-CoPre} \mathrm{should} \mathrm{be} \mathrm{principally} \mathrm{attributed} \mathrm{to} \mathrm{the} \mathrm{existence}$ of higher contents of acid and base active sites. Accordingly, the $\mathrm{Zn} / \mathrm{Sn}$ molar ratio of $2: 1$ calcined at $600^{\circ} \mathrm{C}$ showed a high $96.0 \%$ glycerol conversion and $99.6 \%$ selectivity towards GC at $155^{\circ} \mathrm{C}$ for $4 \mathrm{~h}$. More importantly, the negligible marginal decrease in catalytic activity was also found when recycled for four times. Moreover, it is anticipated that the combinations of porous structures and metal oxides could potentially endow a better catalytic activity $[33,61]$. Interestingly, by using an ingenious heterometallic metal-organic framework (MOF)templated preparation method of chemical transformation at $350^{\circ} \mathrm{C}$, the highly porous nanocage composite consisting welljoined $\mathrm{Co}_{3} \mathrm{O}_{4}$ and $\mathrm{ZnO}$ nanocrystal was triumphantly manufactured and used for GC synthesis from glycerol and urea [62]. Consequently, the as-prepared $\mathrm{Co}_{50} \mathrm{Zn}_{50}-350$ catalyst showed a significantly improved catalytic activity in terms of the high yield of GC over $85.2 \%$ and $91 \%$ GC selectivity, which were superior to those of most solid catalysts. The excellent catalyst 


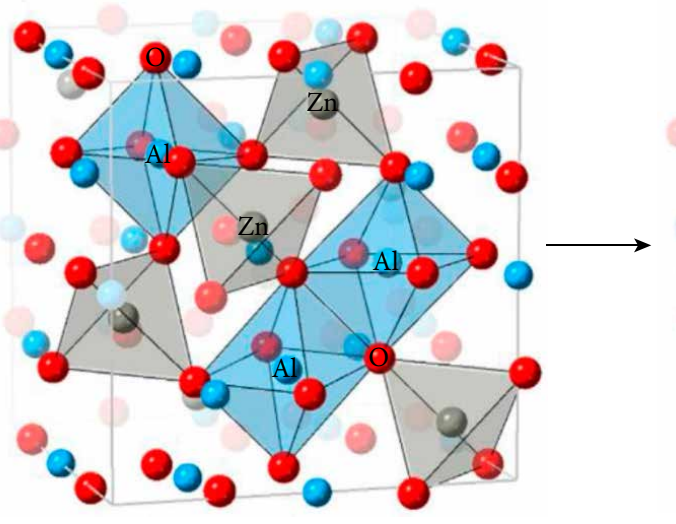

Ordered spinel

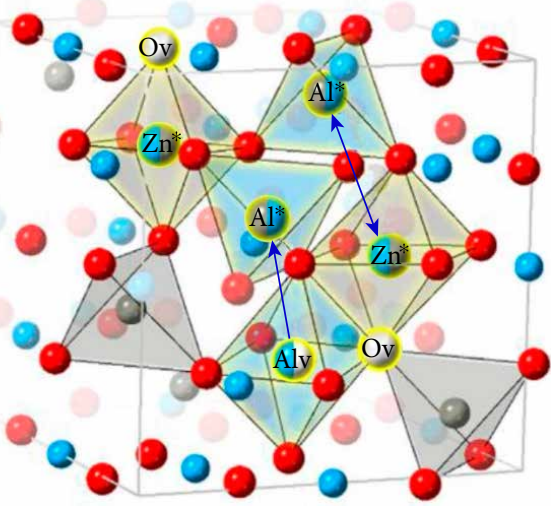

Disordered spinal

(a)

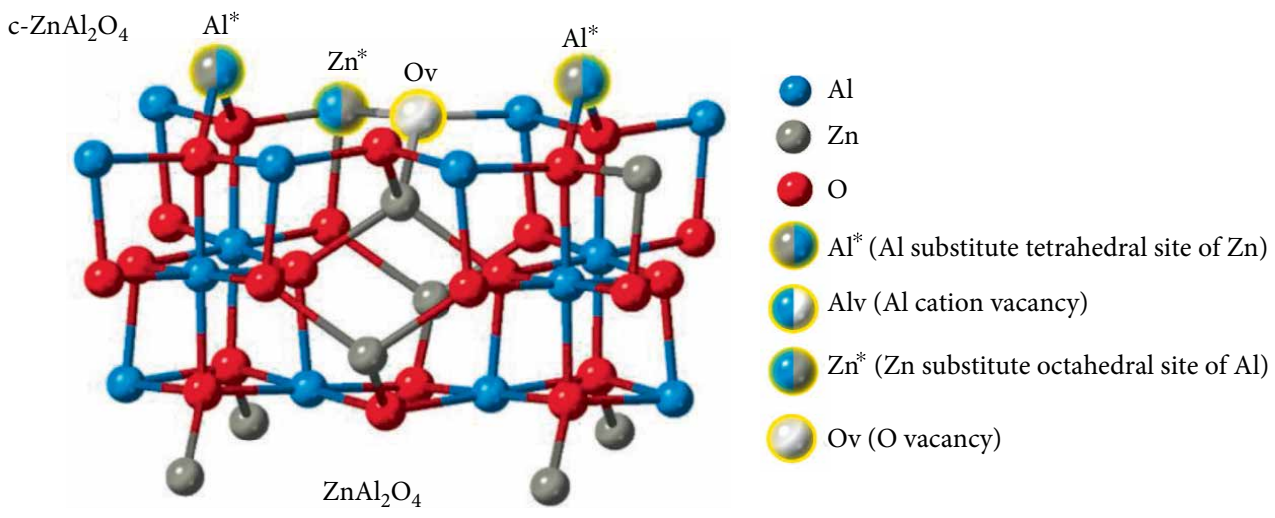

(b)

c-ZnAlO
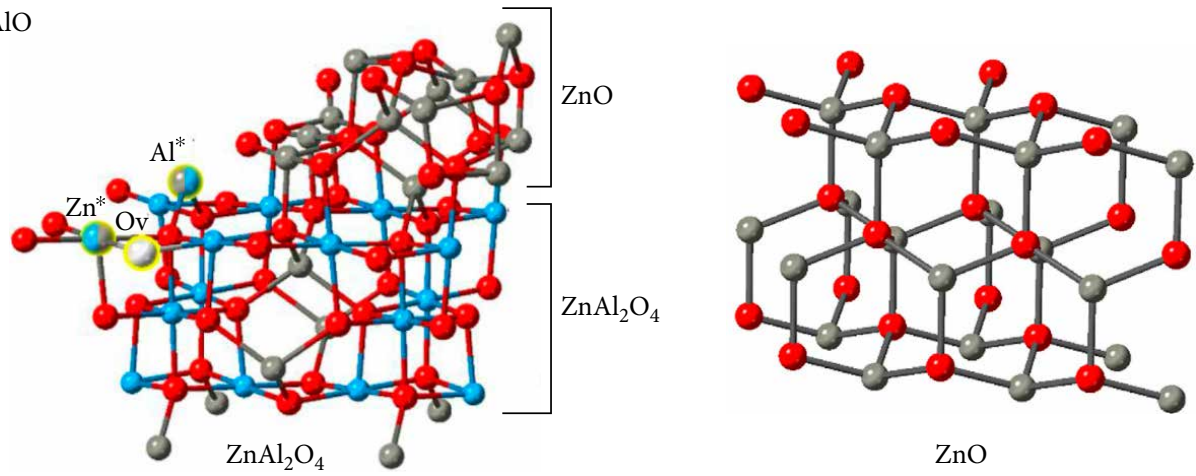

(c)
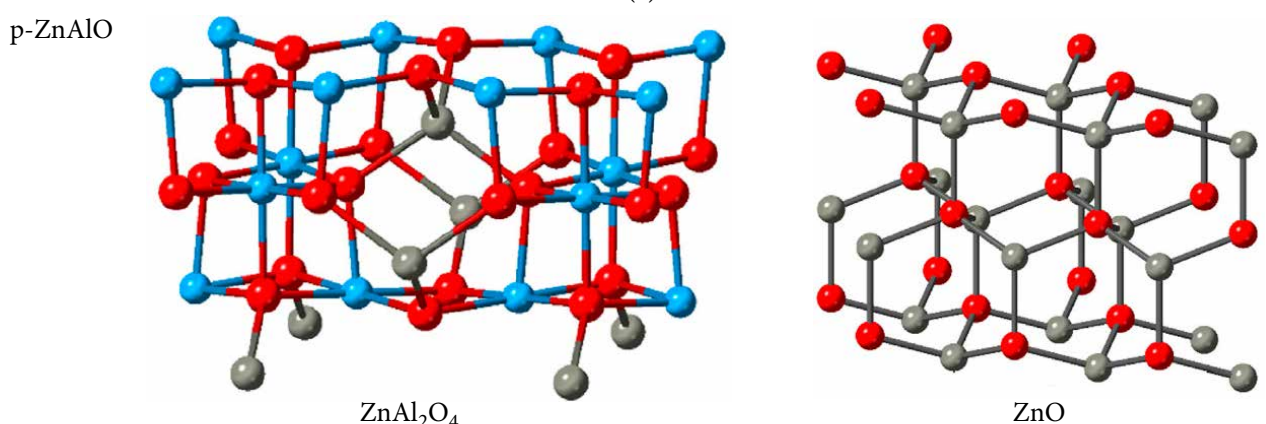

(d)

Scheme 7: Lattice structure of (a) ordered and disordered spinel $\mathrm{ZnAl}_{2} \mathrm{O}_{4}$ phase, (b) c- $\mathrm{ZnAl}_{2} \mathrm{O}_{4}$, (c) c-ZnAlO, and (d) p-ZnAlO [57]. Reproduced from Ref. [57] with permission, Copyright 2019 Elsevier. 
TABLE 1: Catalytic glycerolysis of urea to GC using zinc-based catalyst.

\begin{tabular}{|c|c|c|c|c|c|c|}
\hline Entry & Catalyst & Acid amount $(\mathrm{mmol} / \mathrm{g})$ & Base amount $(\mathrm{mmol} / \mathrm{g})$ & Reaction conditions & Yield of GC (\%) & Ref. \\
\hline 1 & $\mathrm{ZnCl}_{2}$ & $-\mathrm{-a}^{\mathrm{a}}$ & $\mathrm{a}^{\mathrm{a}}$ & $150^{\circ} \mathrm{C}, 2 \mathrm{~h}$ & 80.2 & {$[43]$} \\
\hline 2 & ZMG & $-^{a}$ & $-{ }^{a}$ & $140^{\circ} \mathrm{C}, 7 \mathrm{~h}$ & 83 & [44] \\
\hline 3 & $\mathrm{Zn}-\mathrm{Al}-\mathrm{SO}_{4}$ & 1.58 & $-{ }^{\mathrm{a}}$ & $140^{\circ} \mathrm{C}, 4 \mathrm{~h}$ & 92.8 & [45] \\
\hline 4 & $\mathrm{HT}(\mathrm{Zn} / \mathrm{Al})$ & $-{ }^{a}$ & $-{ }^{a}$ & $130^{\circ} \mathrm{C}, 3 \mathrm{~h}$ & 65.6 & [46] \\
\hline 5 & $\mathrm{Co}_{3} \mathrm{O}_{4} / \mathrm{ZnO}$ & $-^{\mathrm{a}}$ & $-{ }^{\mathrm{a}}$ & $140^{\circ} \mathrm{C}, 4 \mathrm{~h}$ & 69 & {$[52]$} \\
\hline 6 & Porous $\mathrm{ZnO}$ & Integrated area, 5414 & Integrated area, 4042 & $140^{\circ} \mathrm{C}, 6 \mathrm{~h}$ & 85.97 & [53] \\
\hline 7 & $\mathrm{Zn}-\mathrm{Al}-\mathrm{O}$ & 3.43 & 2.76 & $160^{\circ} \mathrm{C}, 5 \mathrm{~h}$ & 82.4 & {$[54]$} \\
\hline 8 & $\mathrm{Zn}_{6} \mathrm{Al}_{4}$ & 0.342 & 0.274 & $140^{\circ} \mathrm{C}, 3 \mathrm{~h}$ & 73 & {$[55]$} \\
\hline 9 & $\mathrm{ZnAlO}$ & 0.375 & 0.383 & $140^{\circ} \mathrm{C}, 3 \mathrm{~h}$ & 68 & {$[56]$} \\
\hline 10 & $\mathrm{ZnAl}_{2} \mathrm{O}_{4}$ & 0.687 & 0.287 & $140^{\circ} \mathrm{C}, 3 \mathrm{~h}$ & 58 & {$[57]$} \\
\hline 11 & $\mathrm{ZnSn-CoPre}$ & 0.268 & 0.061 & $155^{\circ} \mathrm{C}, 4 \mathrm{~h}$ & 95.6 & {$[60]$} \\
\hline 12 & $\mathrm{Co}_{50} \mathrm{Zn}_{50}-350$ & $-^{a}$ & $-^{\mathrm{a}}$ & $150^{\circ} \mathrm{C}, 3 \mathrm{~h}$ & 85.2 & {$[62]$} \\
\hline 13 & $\mathrm{Zn} / \mathrm{MCM}-41(\mathrm{im})$ & 0.02054 & 1.61776 & $145^{\circ} \mathrm{C}, 5 \mathrm{~h}$ & 73.5 & [63] \\
\hline 14 & $5 \% \mathrm{Zn} / \mathrm{MCM}-41$ & 0.5254 & 0.6177 & $140^{\circ} \mathrm{C}, 5 \mathrm{~h}$ & 83 & [64] \\
\hline 15 & Zn-HY-3 & 2.64 & $-{ }^{\mathrm{a}}$ & $150^{\circ} \mathrm{C}, 3 \mathrm{~h}$ & 93 & [65] \\
\hline 16 & $\mathrm{Zn}_{1} \mathrm{TPA}$ & 2.677 & $-{ }^{\mathrm{a}}$ & $140^{\circ} \mathrm{C}, 4 \mathrm{~h}$ & 68.8 & {$[66]$} \\
\hline 17 & $\mathrm{ZnSO}_{4}$ & $-^{\mathrm{a}}$ & $-{ }^{\mathrm{a}}$ & $\begin{array}{l}150^{\circ} \mathrm{C}, 100 \mathrm{~min}, \text { micro- } \\
\text { wave irradiation }(600 \mathrm{~W})\end{array}$ & 93.7 & [81] \\
\hline
\end{tabular}

${ }^{\mathrm{a}}$ Not reported.

performance should be attributed to (a) the abundant active species and remarkable mass transfer of the substrates afforded by the as-synthesized nanocages containing massive pores and (2) the more efficient catalytic roles derived from the establishment of $\mathrm{Co}_{3} \mathrm{O}_{4} / \mathrm{ZnO}$ hetero-interfaces. Unfortunately, the relevant recyclability was not presented.

As mentioned above, the immobilization of active zinc sites onto porous carriers is of significance for achieving high GC yield. With regard to this, $\mathrm{Zn}$ impregnated onto mesoporous MCM-41 support catalyst, Zn/MCM-41(im), was successfully developed and investigated the acid-base sites' roles on GC yield in detail [63]. Thanks to its high surface area of $692 \mathrm{~m}^{2} \mathrm{~g}^{-1}$, well-dispersed $\mathrm{ZnO}$ phase onto the mesoporous framework of MCM-41, and good balanced acid (which activates urea molecules, $0.020 \mathrm{mmol} \mathrm{g}^{-1}$ ) with basic sites (which activates the glycerol, $1.61 \mathrm{mmol} \mathrm{g}^{-1}$ ), 75\% glycerol conversion and $98 \%$ selectivity of GC were determined. Similarly, immobilizing $\mathrm{ZnO}$ catalyst onto the different acid carriers (MCM41, SBA-15, $\mathrm{SiO}_{2}, \mathrm{Al}_{2} \mathrm{O}_{3}, \mathrm{ZrO}_{2}$, and s- $\mathrm{ZrO}_{2}$ ) (5\% Zn/MCM-41, $83 \%$ GC yield at $140^{\circ} \mathrm{C}$ in $5 \mathrm{~h}$ ) [64], $\mathrm{Zn}$-exchanged zeolites including Zn-MOR, Zn-ZSM-5, Zn-beta, and Zn-FAU (Zn$\mathrm{HY}-3,93 \%$ GC yield at $150^{\circ} \mathrm{C}$ for $3 \mathrm{~h}$ ) [65], activated red mud-supported $\mathrm{Zn} / \mathrm{Al}$ oxide catalysts (50\% $\mathrm{Zn} / \mathrm{Al}-\mathrm{ARM}$, $58.1 \%$ GC yield at $140^{\circ} \mathrm{C}$ within $5 \mathrm{~h}$ ) were also reported for efficient transformation of glycerol and urea into GC with relative good yields. Zinc exchanged heteropoly tungstate $\left(\mathrm{Zn}_{x} \mathrm{TPA}\right)$ catalysts were successfully developed and evaluated for selective carbonylation of glycerol with urea to manufacture GC [66]. It was determined that the catalytic performance of $\mathrm{Zn}_{x}$ TPA was mainly decided by the exchangeable $\mathrm{Zn}^{2+}$ ions that were loaded in the secondary structure of heteropoly tungstate. Exchange of protons of TPA with $\mathrm{Zn}^{2+}$ ions could generate acid Lewis and Bronsted sites, simultaneously. Under the reaction temperature of $140^{\circ} \mathrm{C}$ and reaction time of $4 \mathrm{~h}$, $68.8 \%$ GC yield was achieved by using $\mathrm{Zn}_{1}$ TPA catalyst.
Normally, the glycerolysis of urea has to be operated under a vacuum condition or a sweeping gas to eliminate the by-product ammonia, to shift the chemical equilibrium towards the products [67]. Moreover, to our knowledge, previous works on the glycerolysis of urea have been performed in batch operation making it difficult to be applied to industrial-scale $[40,68,69]$. Therefore, it is of high importance to develop a new procedure to prepare GC through the carbonylation of glycerol with urea at atmospheric pressure and continuous operation. With the aim of reducing the by-product $\mathrm{NH}_{3}$ that shifts the thermodynamic chemical equilibrium, the combing of the reaction and separation units in a single reactive distillation column process was developed accordingly [70]. Through this promising process of reactive distillation, the optimal design and operating variables for GC production were no rectifying stage, 3 reactive stage, 3 stripping stages, reflux ratio of 2 , and reboiler heat duty of $15 \mathrm{~kW}$ for each glycerol and urea feed flow rate of $100 \mathrm{~mol} / \mathrm{h}$, giving a high $90.0 \%$ GC yield and 100\% purity of GC. Moreover, compared to the traditional in vacuo manner, reactive distillation improved the glycerol conversion of $29.1 \%$ and saved in energy consumption by $37.1 \%$, accordingly. Importantly, the interesting microwave irradiation technology has been developed and employed in various procedures, like chemical reaction [71, 72], material synthesis [73], nanotechnology [74] and biochemical processes $[75,76]$. It is noteworthy that microwave would improve the product yield and shorten the reaction time in producing carbonates from $\mathrm{CO}_{2}$ and epoxide [77], $\mathrm{NaHCO}_{3}$ and olefins [78], $\mathrm{CO}$ and diols [79], and polycarbonates from open-ring polymerization of trimethylene carbonate [80]. Han et al. performed important research in the synthesis of GC from glycerol and urea with and without the microwave irradiation condition [81]. By using $\mathrm{ZnSO}_{4}$ as the catalyst, the glycerolysis reaction could efficiently proceed with the assistance of microwave, and the high GC yield reached 

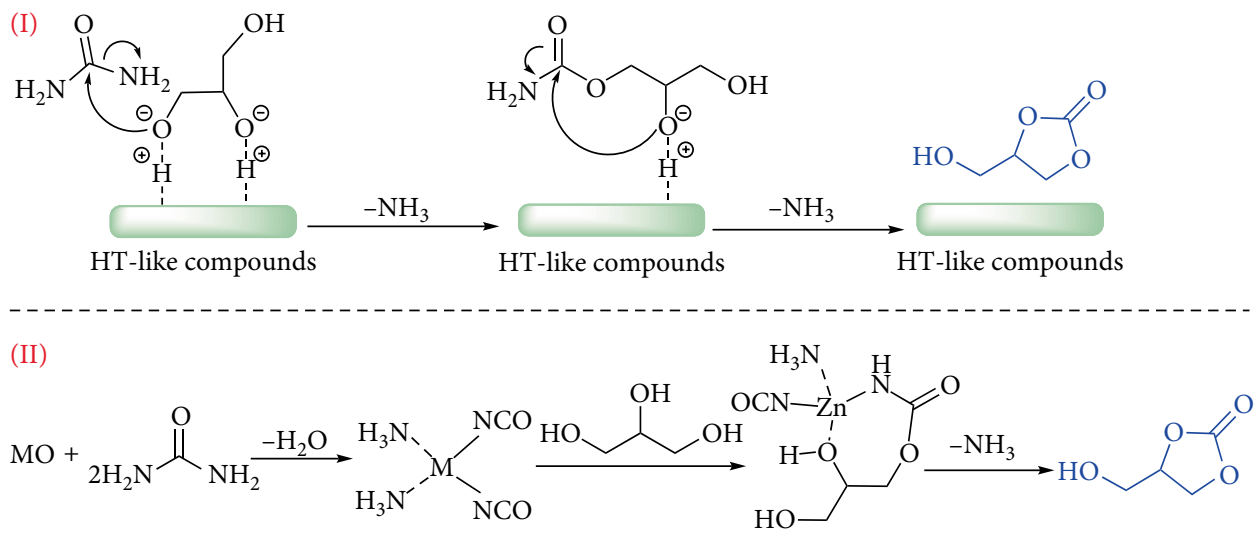

Scheme 8: Proposed mechanism for GC production from glycerol and urea using HT.

TABLE 2: Catalytic glycerolysis of urea to GC using magnesium-based catalyst.

\begin{tabular}{|c|c|c|c|c|c|c|}
\hline Entry & Catalyst & Acid amount (mmol/g) & Base amount $(\mathrm{mmol} / \mathrm{g})$ & Reaction conditions & Yield of GC (\%) & Ref. \\
\hline 1 & $\mathrm{MgO}$ & $-{ }^{\mathrm{a}}$ & $-{ }^{a}$ & $140^{\circ} \mathrm{C}, 5 \mathrm{~h}$ & $70^{\mathrm{b}}$ & [82] \\
\hline 2 & $\begin{array}{c}\text { Combustion } \\
\text { synthesized } \mathrm{MgO}\end{array}$ & 0.69 & 0.73 & $150^{\circ} \mathrm{C}, 6 \mathrm{~h}$ & 71 & [91] \\
\hline 3 & $2.5 \mathrm{wt} \% \mathrm{Au}-\mathrm{MgO}$ & $-{ }^{a}$ & $-^{\mathrm{a}}$ & $150^{\circ} \mathrm{C}, 4 \mathrm{~h}$ & 73 & [95] \\
\hline 4 & $\mathrm{Au}-\mathrm{Pd}-\mathrm{MgO}$ & $-{ }^{a}$ & $--^{a}$ & $150^{\circ} \mathrm{C}, 4 \mathrm{~h}$ & 67 & [96] \\
\hline 5 & $\mathrm{HT}(\mathrm{Mg} / \mathrm{Zn} / \mathrm{Al})$ & $-{ }^{a}$ & $-^{a}$ & $130^{\circ} \mathrm{C}, 3 \mathrm{~h}$ & 83.7 & [97] \\
\hline 6 & $\mathrm{Mg}-\mathrm{Al}-\mathrm{Zr}$ & 0.119 & 0.261 & $140^{\circ} \mathrm{C}, 3 \mathrm{~h}$ & 87.8 & [98] \\
\hline
\end{tabular}

${ }^{\mathrm{a}}$ Not reported. ${ }^{\mathrm{b}}$ Glycerol conversion.

93.7\%. It could be believed that this green and effective process will show a promising prospect in GC production application.

2.2. Reaction with Magnesium-Based Catalyst. As shown in Table 2, magnesium-based catalysts also perform well in GC production from glycerol and urea. Three catalysts involving $\mathrm{ZnO} /$ Zeolite, $\mathrm{PbO} /$ Zeolite, and $\mathrm{MgO}$ were investigated for biodiesel synthesis from Jatropha oil, and the highest biodiesel yield using $\mathrm{ZnO} /$ zeolite reached $93.8 \%$. However, for the utilization of biodiesel byproduct glycerol, $\mathrm{MgO}$ as a catalyst was found to perform better than $\mathrm{ZnO}$ for the production of GC via urea-glycerol [82]. Nearly 70\% glycerol conversion for $\mathrm{MgO}$ at $140^{\circ} \mathrm{C}$ within $5 \mathrm{~h}$ could be presented, which was higher than that of $\mathrm{ZnO}$ with $60 \%$ glycerol conversion. Generally, various protocols for the manufacture of nanocrystalline metal oxides such as inert gas condensation, laser ablation, chemical vapor deposition, sputtering, molecular beam epitaxy, coprecipitation [83], sol-gel process [84], thermal decomposition of nitrates and carbonates [85], and combustion synthesis [86-90] have been reported. Particularly, combustion synthesis was proven to improve the activity, shape selectivity, and to generate more active sites for acid and base catalysts. An eco-friendly manner has been reported in the selective conversion of glycerol and urea to GC using $\mathrm{MgO}$ that was prepared by the combustion method with glycerol as fuel [91]. Up to $71 \%$ glycerol conversion with $100 \%$ selectivity was determined by using the as-prepared $\mathrm{MgO}$ catalyst at $150^{\circ} \mathrm{C}$ for $6 \mathrm{~h}$. In addition, the recoverable and reusable characters of the $\mathrm{MgO}$ catalyst during the consecutive reactions could also be found.
Gold $(\mathrm{Au})$ has attracted great attention because of its catalytic activity serving as the homogeneous and heterogeneous catalysis [92]. Especially, gold was proven to perform well in the selective oxidize glycerol to glyceric acid in aqueous solution [93], and selective solvent-free oxidation of alcohols [94]. More importantly, gold could also serve as an active Lewis acidic catalyst upon being suitably immobilized on the advisable oxides. Therefore, it is of great interest to design the supported gold catalyst for GC synthesis from glycerol and urea. By using a simple impregnation method, the Au immobilized on the supports of titania, carbon, niobium oxide, zinc oxide, and magnesium oxide was successfully developed and tested in GC synthesis [95]. It was reported that the most active catalyst was the $2.5 \mathrm{wt} \% \mathrm{Au}$ deposited on $\mathrm{MgO}$ followed by calcined at $400^{\circ} \mathrm{C}$, showing $73 \%$ yield of $\mathrm{GC}$ at $150^{\circ} \mathrm{C}$ which were superior to that of homogenous zinc sulfate salts. As evidenced in this report, the promotion of the intramolecular cyclization of the carbamate intermediate to generate GC was the key role. More importantly, the catalyst could maintain its catalytic reactivity even after 10 recycles. After this research, bimetallic gold and palladium nanoparticles were further supported on $\mathrm{MgO}$ and utilized as the efficient catalytic material in promoting the synthesis of GC using urea and glycerol as feedstocks [96]. Through both of the sol immobilization and impregnation manners, high dispersions of the vibrant metals could be obtained. Interestingly, the $\mathrm{MgO}$ partly underwent transformations into magnesium carbonate upon reaction since the little impact on reactivity was found. 
The Mg-Al hydrotalcite catalyst was investigated in GC production, and the hydrotalcite-like compounds containing $\mathrm{Mg}, \mathrm{Zn}$, and $\mathrm{Al}$ metals showed an excellent catalytic performance [97]. Consequently, $89.8 \%$ conversion of glycerol and $93.2 \%$ selectivity for GC were presented under $130^{\circ} \mathrm{C}$ for $3 \mathrm{~h}$ by using $\mathrm{HT}(\mathrm{Mg} / \mathrm{Zn} / \mathrm{Al})$ catalyst. Furthermore, the proposed reaction mechanism realized with two routes promoted by hydrotalcite-like compounds is depicted in Scheme 8. As reported in this research, Route I was deemed as the possible heterogeneous mechanism. Firstly, a bidentate ligand was formed through the coordination of glycerol with HT via hydrogen bond, wherein the oxygen atoms would be activated. The oxygen of the primary alcohol attacked the carbonylic carbon of urea that might generate $\mathrm{NH}_{3}$. Afterward, the oxygen of the secondary hydroxyl group further attacked the carbonylic carbon through the intramolecular transesterification, which is supported because of the stable five-member cycle structure. The second $\mathrm{NH}_{3}$ was also produced and GC would be detached from the surface of HT. Route II should be a plausible homogeneous mechanism. Initially, the metal complex was generated, wherein the two $\mathrm{NH}_{3}$ from urea were weakly coordinated. Then, one of the coordinated $\mathrm{NH}_{3}$ was exchanged with glycerol, leading to the intermediate to which glycerol interacted with the metal centers by their oxygen. Followed by this, the interacting hydroxyl groups of glycerol captured the adjacent isocyanate groups. Finally, the coordinated carbamate groups would be converted into GC by intracyclization, releasing $\mathrm{NH}_{3}$ and the catalytic active ingredients. After that, a sequence of $\mathrm{Mg}-\mathrm{Al}$ hydrotalcite-like ( $\mathrm{HTl}$ ) catalysts doped with $\mathrm{Zr}$ bearing the mesoporous structures upon under heat treatment were also developed and employed for GC production from glycerol and urea [98]. As a result, the well-balanced surface acid and base active sites of the catalyst with $\mathrm{Zr}^{4+}:\left(\mathrm{Al}^{3+}+\mathrm{Zr}^{4+}\right)=0.3$ demonstrated the highest $87.8 \%$ yield of GC at $140^{\circ} \mathrm{C}$ within $3 \mathrm{~h}$.

2.3. Reaction with Tungsten-Based Catalyst. In Table 3, tungsten-based catalysts also show interesting works regarding GC synthesis. A series of tungsten (W)-tin (Sn) mixed oxides with varied mole ratios were synthesized using the coprecipitation process and evaluated for GC production from glycerol and urea [99]. Sn-W catalyst with a 2:1 molar ratio calcined at $500^{\circ} \mathrm{C}$ showed the best catalytic performance in terms of $52 \%$ of glycerol conversion with $>95 \%$ GC selectivity. Similarly, different $\mathrm{WO}_{3}$ contents supported on $\mathrm{SnO}_{2}$ catalytic materials were prepared and employed for GC synthesis [100]. In situ Raman technology revealed the existence of isolated monomers and polymeric species of $\mathrm{WO}_{3}$. Accordingly, the glycerol conversion and selectivity were found to be depended on the well-dispersed amorphous $\mathrm{WO}_{3}$ which in turn was related to the acidity of the catalysts. The catalyst with $5 \mathrm{wt} \%$ $\mathrm{WO}_{3}$ on $\mathrm{SnO}_{2}$ calcined at $500^{\circ} \mathrm{C}$ for $4 \mathrm{~h}$ brought about the high dispersions of larger contents of strong acid active sites, giving $85.4 \%$ selectivity towards GC at $140^{\circ} \mathrm{C}$ in $4 \mathrm{~h}$. Following up these valuable studies, tungsten oxide species supported on titania catalysts ( $100 \%$ selectivity for GC, $140^{\circ} \mathrm{C}$ in $4 \mathrm{~h}$ ) [101], silicotungstates impregnated into MCM-41 (77\% selectivity for $\mathrm{GC}, 150^{\circ} \mathrm{C}$ in $8 \mathrm{~h}$ ) [102], silicotungstates anchored to large pore zeolite $\mathrm{H} \beta$ ( $75 \%$ selectivity for $\mathrm{GC}, 150^{\circ} \mathrm{C}$ in $8 \mathrm{~h}$ ) [103] were also developed for GC synthesis with authentic and acceptable results.

Early transition metals formed in the metal-oxygen clusters of their highest oxidation state, also known as polyoxometalates (HPA), are a group of important inorganic compounds showing large potential application prospects in catalysis [104-106]. Due to their compelling features of strong Brønsted acidity, multistage redox activity, and remarkable thermal and hydrolytic stability, polyoxometalates have been applied in acid and oxidation catalysis. In addition, the catalytic properties can be tuned by proton exchange of the HPA with various metal or alkali ions. For instance, the proton exchange of tungstophosphoric acid with $\mathrm{Cs}^{+}$generated a strong acid in comparison with the pristine acid [107]. In a similar manner, exchanging the protons of the HPA with $\mathrm{Sn}^{2+}$ and $\mathrm{Al}^{3+}$ resulted in the Lewis acidic sites [108-110]. In this context, samarium-exchanged heteropoly tungstate catalyst $\left(\mathrm{Sm}_{x} \mathrm{TPA}\right)$ was designed and used for GC synthesis, aiming to enhance the acidity thereby increasing GC yield accordingly [111]. The activity of the catalysts was determined to depend on the Lewis and Brønsted acidity that came from the Sm contents, and the partially exchanged $\mathrm{Sm}_{x} \mathrm{TPA}$ catalysts exhibited the best performance, due to the higher amounts of Lewis acid sites. As illustrated in Scheme 9, the plausible reaction mechanism using $\mathrm{Sm}_{x}$ TPA catalysts was also proposed by the authors. In short, Lewis and Brønsted acidic sites activated the carbonyl group of urea, the conjugate base, and the hydroxyl group of the glycerol. Cs-exchanged heteropolyacid catalysts functionalized with $\mathrm{Sn}, \mathrm{Sn}-\mathrm{CsPW}\left(83 \% \mathrm{GC}\right.$ selectivity, $\left.140^{\circ} \mathrm{C}\right)$ [112], tantalum exchanged tungstophosphoric acid catalysts $\left(100 \% \mathrm{GC}\right.$ selectivity, $\left.140^{\circ} \mathrm{C}\right)$ [113] were also developed for GC synthesis from glycerol and urea.

2.4. Reaction with Functional Ionic Liquid. Using ionic liquids (ILs) as catalysts to produce GC via urea-glycerol is also presented in Table 4. Acidic, basic, and neutral ILs were adopted as the catalysts for GC production through glycerolysis of glycerol with urea [114]. Interestingly, neutral ILs were determined to perform best while acid and base ILs exhibited the poor activity. The well-balanced acid-base properties of the neutral ILs that were derived from the synergistic effect of the cations and anions, were treated as the key role in obtaining high GC yield. The positively charged cation activated urea by attracting the electronegative oxygen of the carbonyl group of urea, which was similar to that of Lewis acid site. On the other hand, the negatively charged anion attracted the proton of glycerol at the same time. Moreover, the IL catalysts could be recycled and reused at least 5 times without significant activity decrease. Nonetheless, the obvious difficulty in separation and recovery will limit ILs to be applicated on a large scale [115]. Of particular interest is to immobilize ILs through heterogenization of ILs onto suitable solid supports like organic polymers and inorganic materials $[116,117]$. By the reaction of imidazole with alkoxylated Merrifield peptide resin (MPR), ILs incorporated on the MPR catalysts MPR-ILs were successfully developed [118]. MPR-ILs with longer alkyl chains and fewer sterically hindered counteranions demonstrated better catalytic performance in GC synthesis, giving $80.9 \%$ 


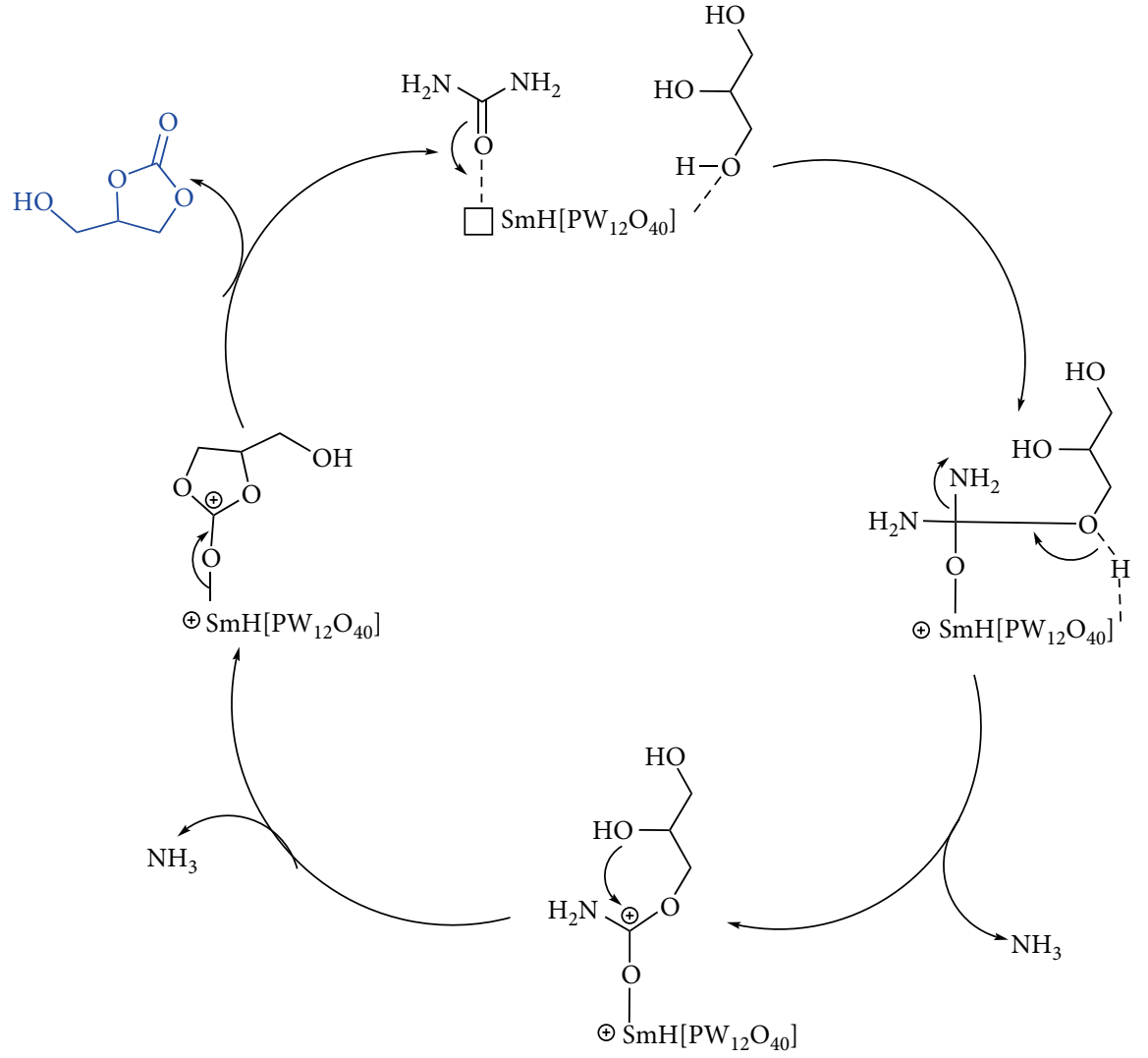

Scheme 9: Proposed reaction mechanism using $\mathrm{Sm}_{\mathrm{x}} \mathrm{TPA}$ catalyst.

TABLE 3: Catalytic glycerolysis of urea to GC using tungsten-based catalyst.

\begin{tabular}{|c|c|c|c|c|c|c|}
\hline Entry & Catalyst & Acid amount $(\mathrm{mmol} / \mathrm{g})$ & Base amount (mmol/g) & Reaction conditions & Yield of GC (\%) & Ref. \\
\hline 1 & SW21 & 0.472 & $-{ }^{\mathrm{a}}$ & $140^{\circ} \mathrm{C}, 4 \mathrm{~h}$ & 49.4 & [99] \\
\hline 2 & $5 \mathrm{wt} \% \mathrm{WO}_{3}-\mathrm{SnO}_{2}$ & 0.271 & $-{ }^{a}$ & $140^{\circ} \mathrm{C}, 4 \mathrm{~h}$ & $85.4^{\mathrm{b}}$ & [100] \\
\hline 3 & $15 \% \mathrm{WO}_{3} / \mathrm{TiO}_{2}$ & 0.554 & $-{ }^{\mathrm{a}}$ & $140^{\circ} \mathrm{C}, 4 \mathrm{~h}$ & 73 & [101] \\
\hline 4 & $30 \% \mathrm{SiW}_{12} / \mathrm{MCM}-41$ & 3.4 & $-{ }^{a}$ & $150^{\circ} \mathrm{C}, 8 \mathrm{~h}$ & $77^{\mathrm{b}}$ & [102] \\
\hline 5 & $\mathrm{SiW}-\mathrm{H} ß$ & 3.5 & $-{ }^{\mathrm{a}}$ & $150^{\circ} \mathrm{C}, 8 \mathrm{~h}$ & $75^{\mathrm{b}}$ & [103] \\
\hline 6 & $\mathrm{Sm}_{0.66} \mathrm{TPA}$ & 1.726 & $-{ }^{\mathrm{a}}$ & $140^{\circ} \mathrm{C}, 4 \mathrm{~h}$ & $85^{\mathrm{b}}$ & [111] \\
\hline 7 & Sn-CsPW & 528 & $-{ }^{a}$ & $140^{\circ} \mathrm{C}, 4 \mathrm{~h}$ & $85^{\mathrm{b}}$ & [112] \\
\hline 8 & $\mathrm{Ta}_{0.4} \mathrm{TPA}$ & 0.128 & $-{ }^{\mathrm{a}}$ & $140^{\circ} \mathrm{C}, 4 \mathrm{~h}$ & $100^{\mathrm{b}}$ & [113] \\
\hline
\end{tabular}

${ }^{\mathrm{a}}$ Not reported. ${ }^{\mathrm{b}} \mathrm{GC}$ selectivity.

selectivity of GC at $140^{\circ} \mathrm{C}$ for $3 \mathrm{~h}$. High temperature, high degree of vacuum and the addition of co-catalyst of $\mathrm{ZnO}$ could improve the GC selectivity to $100 \%$.

As depicted in Scheme 10, the Zn-containing ILs immobilized on the polymeric support polystyrene (PS) PS-(Im) ${ }_{2} \mathrm{ZnBr}_{2}$, was successfully developed and employed for GC production [119]. PS- $(\mathrm{Im})_{2} \mathrm{ZnBr}_{2}$ was prepared through two steps: (1) bis[1-(2-hydroxyethyl)imidazolium]zinc bromide (HEIm) ${ }_{2} \mathrm{ZnBr}_{2}$ was synthesized via metal insertion; (2) the $(\mathrm{HEIm})_{2} \mathrm{ZnBr}_{2}$ was incorporated into MPR by alkoxylation. Under the reaction temperature of $140^{\circ} \mathrm{C}$ for 6 h, $72.3 \%$ selectivity of GC was achieved using (HEIm) ${ }_{2} \mathrm{ZnBr}_{2}$ catalyst because of its well-balanced acid-base properties. In addition, the as-synthesized catalyst could be reused for 4 times with $70.1 \%$ selectivity of GC. Various quaternary ammonium salts (QX) ILs supported onto montmorillonite clay (Q-MMT) were manufactured through the ion-exchange method between the tetra-alkyl ammonium salts and ions in the clay interlayer [120]. By the detailed investigations, the Q-MMTs were found to perform well in the selective synthesis of GC from glycerol and urea, showing $80 \%$ selectivity of GC at $145^{\circ} \mathrm{C}$ within $3 \mathrm{~h}$. More importantly, Q-MMT could be easily reused during 4 recycles without any significant activity decrease. Similar to [119], polystyrene immobilized with different kinds $(\mathrm{Cu}, \mathrm{Mg}, \mathrm{Zn})$ of metal-containing imidazolium salt $\left[\mathrm{PS}-(\mathrm{Im})_{2} \mathrm{MX}_{2}\right]$ catalysts were prepared and used for GC production [121]. Among different metal-containing PS- $(\mathrm{Im})_{2} \mathrm{MBr}_{2}$ catalytic materials, the yield of GC increased 

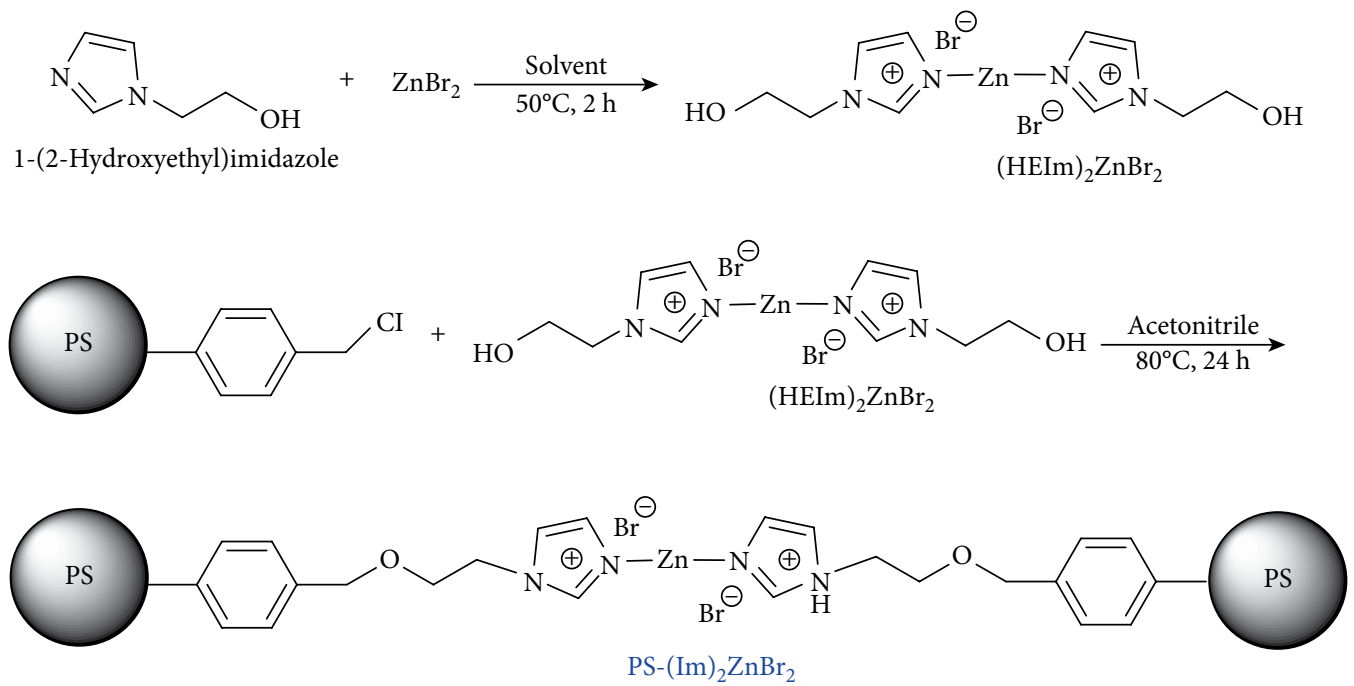

Scheme 10: The synthetic route for PS-(Im) $)_{2} \mathrm{ZnBr}_{2}$.

TABLE 4: Catalytic glycerolysis of urea to GC using ILs-based catalyst.

\begin{tabular}{lcccccc}
\hline Entry & Catalyst & Acid amount $(\mathrm{mmol} / \mathrm{g})$ & Base amount $(\mathrm{mmol} / \mathrm{g})$ & Reaction conditions & Yield of GC $(\%)$ & Ref. \\
\hline 1 & $\mathrm{MPR}[\mathrm{pmim}][\mathrm{Cl}]+$ & $-^{\mathrm{a}}$ & $-^{\mathrm{a}}$ & $140^{\circ} \mathrm{C}, 3 \mathrm{~h}$ & 78.6 & {$[118]$} \\
& $\mathrm{ZnO}$ & 0.165 & 0.66 & $140^{\circ} \mathrm{C}, 6 \mathrm{~h}$ & $72.3^{\mathrm{b}}$ & {$[119]$} \\
2 & $\mathrm{PS}-(\mathrm{Im})_{2} \mathrm{ZnBr}_{2}$ & $-^{\mathrm{a}}$ & 0.97 & $145^{\circ} \mathrm{C}, 3 \mathrm{~h}$ & $80^{\mathrm{b}}$ & {$[120]$} \\
3 & $\mathrm{Q}-\mathrm{MMTs}$ & 6.01 & 6.67 & $140^{\circ} \mathrm{C}, 6 \mathrm{~h}$ & 60.3 & {$[121]$} \\
4 & {$\left[\mathrm{PS}-(\mathrm{Im})_{2} \mathrm{MX}_{2}\right]$} & & & &
\end{tabular}

${ }^{\mathrm{a}}$ Not reported. ${ }^{\mathrm{b}} \mathrm{GC}$ selectivity.

TABLE 5: Catalytic glycerolysis of urea to GC with other catalysts.

\begin{tabular}{|c|c|c|c|c|c|c|}
\hline Entry & Catalyst & $\begin{array}{l}\text { Acid amount } \\
(\mathrm{mmol} / \mathrm{g})\end{array}$ & Base amount $(\mathrm{mmol} / \mathrm{g})$ & $\begin{array}{l}\text { Reaction condi- } \\
\text { tions }\end{array}$ & Yield of GC (\%) & Ref \\
\hline 1 & $\mathrm{La}_{2} \mathrm{O}_{3}$ & $-^{\mathrm{a}}$ & 0.108 & $140^{\circ} \mathrm{C}, 1 \mathrm{~h}$ & 90 & [124] \\
\hline 2 & $\mathrm{La}_{2} \mathrm{Cu}_{0.5} \mathrm{Fe}_{0.5} \mathrm{O}_{4}$ & $\begin{array}{l}\text { Qualitatively, not } \\
\text { quantitatively }\end{array}$ & $\begin{array}{l}\text { Qualitatively, not } \\
\text { quantitatively }\end{array}$ & $150^{\circ} \mathrm{C}, 4 \mathrm{~h}$ & $81.9^{\mathrm{b}}$ & [125] \\
\hline 3 & $\mathrm{Cu}^{1} \mathrm{Mn}$ & $\begin{array}{c}\text { Qualitatively, not } \\
\text { quantitatively }\end{array}$ & $\begin{array}{c}\text { Qualitatively, not } \\
\text { quantitatively }\end{array}$ & $140^{\circ} \mathrm{C}, 6 \mathrm{~h}$ & $99.1^{\mathrm{b}}$ & [126] \\
\hline 4 & AlCaMO & $\begin{array}{l}\text { Qualitatively, not } \\
\text { quantitatively }\end{array}$ & $\begin{array}{l}\text { Qualitatively, not } \\
\text { quantitatively }\end{array}$ & $145^{\circ} \mathrm{C}, 5 \mathrm{~h}$ & $88^{\mathrm{b}}$ & {$[68]$} \\
\hline 5 & $\gamma$-Zirconium phosphate & 1.49 & 0.18 & $135^{\circ} \mathrm{C}, 3 \mathrm{~h}$ & $100^{\mathrm{b}}$ & [127] \\
\hline 6 & Waste boiler ash & $-{ }^{\mathrm{a}}$ & 7.1 & $150^{\circ} \mathrm{C}, 4 \mathrm{~h}$ & 84.3 & [128] \\
\hline 7 & Gypsum-based catalyst & 0.12 & $-{ }^{\mathrm{a}}$ & $150^{\circ} \mathrm{C}, 4 \mathrm{~h}$ & 83.6 & [129] \\
\hline
\end{tabular}

${ }^{\mathrm{a}}$ Not reported. ${ }^{\mathrm{b}} \mathrm{GC}$ selectivity.

$\mathrm{Cu}<\mathrm{Mg}<\mathrm{Zn}$, which follows the order of acid-base balance of the catalysts wherein $\mathrm{Zn}$-containing catalyst presented better $\mathrm{acid} / \mathrm{base}$ ratio than those of $\mathrm{Mg}$ and $\mathrm{Cu}$.

2.5. Reaction with Other Catalysts. In addition to the catalytic materials mentioned above, some other catalysts illustrated in Table 5 also demonstrate good results for GC production. Commercial polymeric cation resin Amberlyst-15 was used for GC synthesis from urea and glycerol with $62.76 \%$

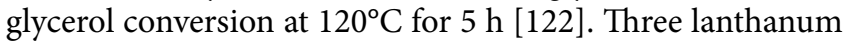

(La) based catalysts were also developed in the synthesis of GC, including $\mathrm{LaCl}_{3}$ [123], $\mathrm{La}_{2} \mathrm{O}_{3}$ [124], and $\mathrm{La}_{2} \mathrm{Cu}_{0.5} \mathrm{Fe}_{0.5} \mathrm{O}_{4}$ [125]. For $\mathrm{LaCl}_{3}$ catalyzed glycerolysis, the key reaction mechanism is illustrated in Scheme 11. Three oxygen atoms of the carbonyl group of the 2,3-dihydroxypropyl carbamate (HPC) coordinated with $\mathrm{La}^{3+}$ of $\mathrm{LaCl}_{3}$; the electrons of $\mathrm{C}-\mathrm{N}$ groups redistributed wherein the proton transferred onto the carbon atom leading to the carbocation and nitrogen anion and favoring the intramolecular nucleophilic attack of adjoining hydroxyl group. Consequently, there was the 


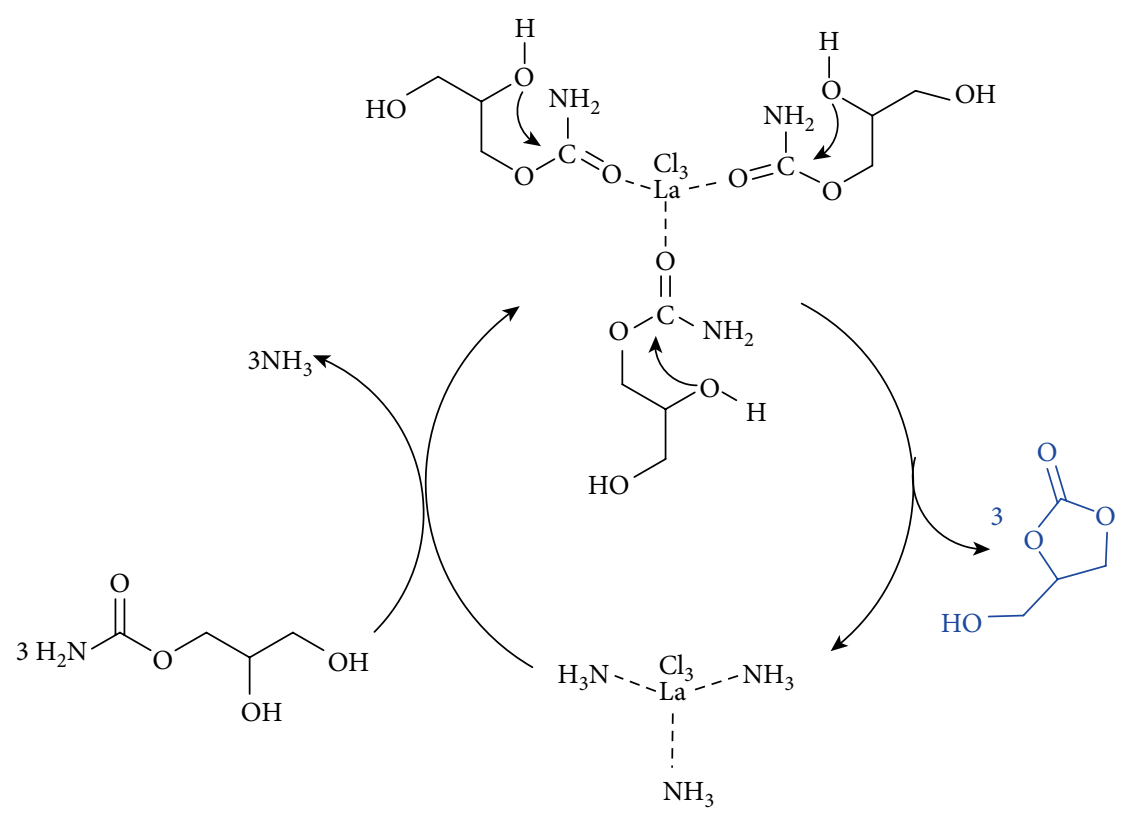

SCHEME 11: The proposed reaction mechanism for GC synthesis from HPC over $\mathrm{LaCl}_{3}$.

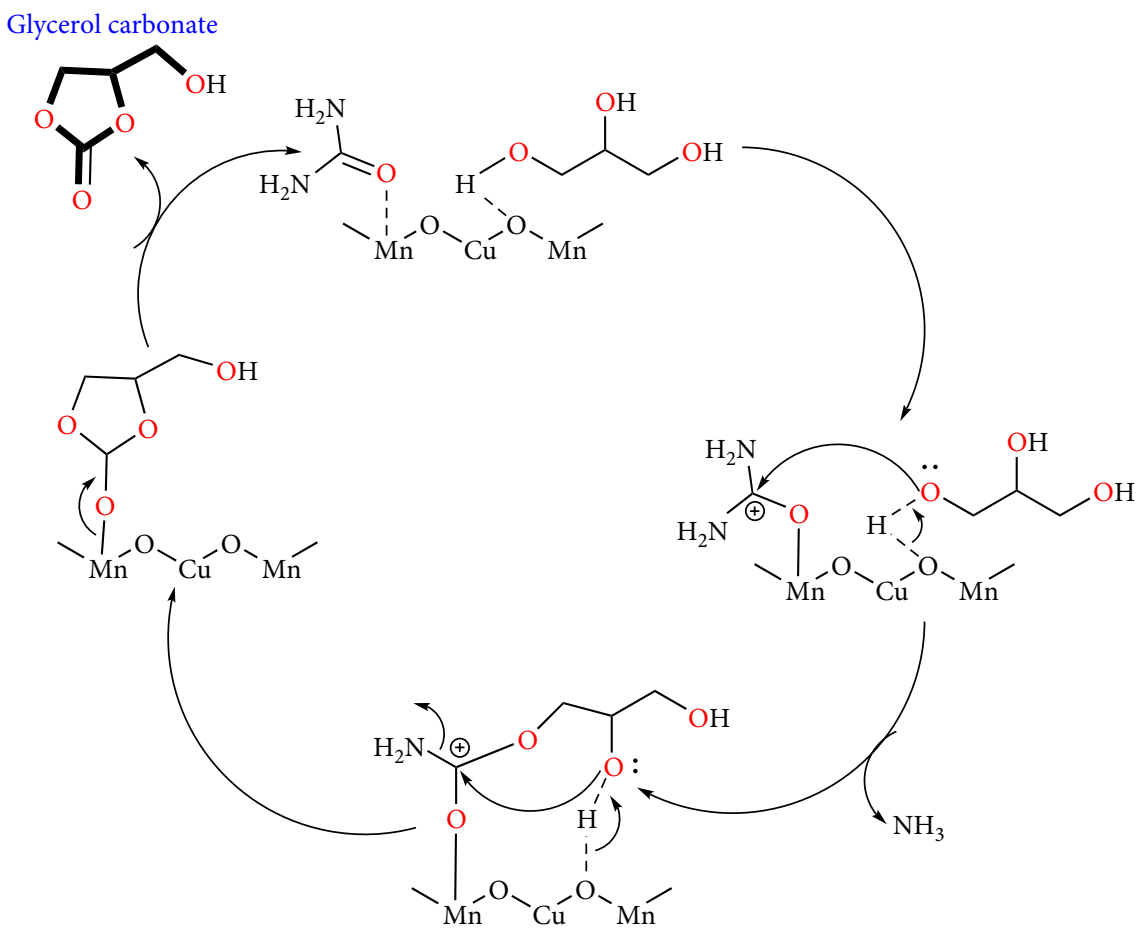

SCHEme 12: The possible reaction mechanism for the synthesis of GC by $\mathrm{Cu}-\mathrm{Mn}$ composites.

important bond between the electrophilic carbonyl carbon of complex and the lone pair of electrons of oxygen of the hydroxyl group. Meanwhile, the hydrogen protons broke away from the hydroxyl groups united with the amino groups leaving from the formed complexes. At last, the final product GC was generated by the broke of $\mathrm{C}-\mathrm{N}$ bond and the new formation of $\mathrm{C}-\mathrm{O}$ bond, while the corresponding complex $\mathrm{La}\left(\mathrm{NH}_{3}\right)_{3} \mathrm{Cl}_{3}$ could be also regenerated. In addition, due to the strong nucleophilicity of $\mathrm{HPC}$ and the release of $\mathrm{NH}_{3}$, the catalytic circulation was finished accompanied by the substitution of $\mathrm{NH}_{3}$ molecules with HPC.

$\mathrm{Cu}-\mathrm{Mn}$ composite oxides prepared by coprecipitation method (99.1\% GC selectivity, $140^{\circ} \mathrm{C}$ for $6 \mathrm{~h}$ ) [126], $\mathrm{Al} /$ Ca-mixed oxide (AlCaMO) derived from hydrotalcite (88\% GC selectivity, $145^{\circ} \mathrm{C}$ for $5 \mathrm{~h}$ ) [68], $\gamma$-zirconium phosphate ( $100 \% \mathrm{GC}$ selectivity, $135^{\circ} \mathrm{C}$ for $3 \mathrm{~h}$ ) [127], waste boiler 
ash (90.1\% GC selectivity, $150^{\circ} \mathrm{C}$ for $\left.4 \mathrm{~h}\right)$ [128], and gypsum-based catalyst $\left(90.1 \%\right.$ GC selectivity, $150^{\circ} \mathrm{C}$ for $4 \mathrm{~h}$ ) [129] were developed for GC manufacture. For the GC production catalyzed by $\mathrm{Cu}-\mathrm{Mn}$ composites (Scheme 12 ), $\mathrm{Cu}_{1.4} \mathrm{Mn}_{1.6} \mathrm{O}_{4}$ crystal phase was determined as the active species in glycerolysis. It was reported that this phase can efficiently afford acid sites of $\mathrm{Mn}^{4+}$ and lattice oxygen $\mathrm{O}^{2-}$ base sites, and the presence of the $\mathrm{Mn}^{4+}-\mathrm{O}^{2-}$ Lewis acid-base pairs would facilitate the transformation of glycerol and urea into GC, consequently.

\section{Conclusion}

The effective production of glycerol carbonate (GC) has been arousing great attention because of its importance in lessening excessive glycerol in biodiesel process as well as its potential industrial application prospect, especially in the polymer area. Selective catalytic valorization of glycerol with urea by carbonylation into GC has been shown to be the most promising in terms of the reactants available and reaction environmental benefits. Although the sole acidic or basic site can exhibit some reactivity for glycerolysis of urea, the achievement of high conversion and high selectivity of GC using recyclable heterogeneous catalysts remains a great challenge. On the one hand, the strong interaction between urea and acid sites will lead to the deactivation of active sites for further procedures. On the other hand, the undesirable reactions like decarbonylation and 2-HPC dehydration can be accelerated by the base and the GC selectivity will decrease due to the overmuch amounts of basic sites. Consequently, the catalysts with the appropriate balance of active acidic and basic sites will be favorable for the synthesis of GC from glycerol and urea. Moreover, the energetical development of heterogeneous catalysts of high-performance for this process demonstrates the powerful and significant strategic and environmental benefits.

It is noteworthy that the catalytic activity of catalysts can be considerably improved by the rationale regulating their compositions and surface structures. As anticipated, the joint application of pore formation such as well-defined ordered channel frameworks and catalytic active species combinations would potentially enable the promising environmentally friendly catalysts. In addition, insightful reaction mechanisms and structure-property understanding will also help us to design the appropriate catalysts for GC manufacture from glycerol and urea. Finally, the proper employment of the relevant auxiliaries to boost catalytic activity and product selectivities, such as heating modes of microwave irradiation and reactive distillation replacing the traditional in vacuo system are also suggested.

\section{Conflicts of Interest}

The authors have no conflicting interests to declare.

\section{Acknowledgments}

This work was financially supported by the Natural Science Foundation of China (21576059, 21666008, 21908033), Chinese Scholarship Council (CSC, No. 201706670012), Fok Ying Tong Education Foundation (161030), and Guizhou Science \& Technology Foundation ([2018]1037).

\section{References}

[1] Y. Zhu, C. Romain, and C. K. Williams, "Sustainable polymers from renewable resources," Nature, vol. 540, no. 7633, pp. 354-362, 2016.

[2] H. Zhang, Y. Hu, L. Qi, J. He, H. Li, and S. Yang, "Chemocatalytic production of lactates from biomass-derived sugars," International Journal of Chemical Engineering, vol. 2018, Article ID 7617685, 18 pages, 2018.

[3] X. Yao, H. Liu, and C. Li, "Development of eco-friendly soy meal adhesives enhanced by ethylene glycol diglycidyl ether," Advances in Polymer Technology, vol. 2019, Article ID 8697047, 7 pages, 2019.

[4] Q. Yu, Y. Wang, X. Cao et al., "One-step formation of chondrocytes through direct reprogramming via polysaccharide-based gene delivery," Advances in Polymer Technology, vol. 2019, Article ID 7632873, 12 pages, 2019.

[5] J. R. Jambeck, R. Geyer, C. Wilcox et al., "Plastic waste inputs from land into the ocean," Science, vol. 347, no. 6223, pp. 768-771, 2015.

[6] H. Zhang, H. Pan, and S. Yang, "Upgrading of cellulose to biofuels and chemicals with acidic nanocatalysts," Current Nanoscience, vol. 13, no. 5, pp. 513-527, 2017.

[7] H. Zhang, H. Li, H. Pan et al., "Magnetically recyclable acidic polymeric ionic liquids decorated with hydrophobic regulators as highly efficient and stable catalysts for biodiesel production," Applied Energy, vol. 223, pp. 416-429, 2018.

[8] J. C. Philp, A. Bartsev, R. J. Ritchie, M. A. Baucher, and K. Guy, "Bioplastics science from a policy vantage point," New Biotechnology, vol. 30, no. 6, pp. 635-646, 2013.

[9] F. Ferdosian, Y. Zhang, Z. Yuan, M. Anderson, and C. C. Xu, "Curing kinetics and mechanical properties of bio-based epoxy composites comprising lignin-based epoxy resins," European Polymer Journal, vol. 82, pp. 153-165, 2016.

[10] B. Li, S. Feng, H. Niasar et al., "Preparation and characterization of bark-derived phenol formaldehyde foams," RSC Advances, vol. 6, no. 47, pp. 40975-40981, 2016.

[11] H. Zhang and M. W. Grinstaff, "Recent advances in glycerol polymers: chemistry and biomedical applications," Macromolecular Rapid Communications, vol. 35, no. 22, pp. 1906-1924, 2014.

[12] C. H. C. Zhou, J. N. Beltramini, Y. X. Fan, and G. M. Lu, "Chemoselective catalytic conversion of glycerol as a biorenewable source to valuable commodity chemicals," Chemical Society Reviews, vol. 37, no. 3, pp. 527-549, 2008.

[13] H. Pan, X. Liu, H. Zhang, K. Yang, S. Huang, and S. Yang, "Multi- $\mathrm{SO}_{3} \mathrm{H}$ functionalized mesoporous polymeric acid catalyst for biodiesel production and fructose-to-biodiesel 
additive conversion," Renewable Energy, vol. 107, pp. 245-252, 2017.

[14] H. Zhang, H. Li, H. Pan, A. Wang, C. C. Xu, and S. Yang, "Magnetically recyclable basic polymeric ionic liquids for efficient transesterification of Firmiana platanifolia L.f. oil into biodiesel," Energy Conversion and Management, vol. 153, pp. 462-472, 2017.

[15] H. Li, Z. Fang, R. L. SmithJr, and S. Yang, "Efficient valorization of biomass to biofuels with bifunctional solid catalytic materials," Progress in Energy and Combustion Science, vol. 55, pp. 98-194, 2016.

[16] H. Zhang, H. Li, Y. Hu, K. T. V. Rao, C. C. Xu, and S. Yang, "Advances in production of bio-based ester fuels with heterogeneous bifunctional catalysts," Renewable and Sustainable Energy Reviews, vol. 114, p. 109296, 2019.

[17] K. L. Yang, S. Huang, H. Pan, H. Zhang, X. F. Liu, and S. Yang, "Polyoxometalate- $\mathrm{MgF}_{2}$ hybrids as heterogeneous solid acid catalysts for efficient biodiesel production," RSC Advances, vol. 7, no. 53, pp. 33335-33343, 2017.

[18] H. Zhang, H. Li, C. Xu, and S. Yang, "Heterogeneously chemo/ enzyme-functionalized porous polymeric catalysts of highperformance for efficient biodiesel production," ACS Catalysis, vol. 9, pp. 10990-11029, 2019.

[19] A. Wang, H. Li, H. Zhang, H. Pan, and S. Yang, "Efficient catalytic production of biodiesel with acid-base bifunctional rod-like Ca-B oxides by the sol-gel approach," Materials, vol. 12 , no. 1 , p. 83, 2019.

[20] C. H. Zhou, H. Zhao, D. S. Tong, L. M. Wu, and W. H. Yu, "Recent advances in catalytic conversion of glycerol," Catalysis Reviews, vol. 55, no. 4, pp. 369-453, 2013.

[21] H. Pan, H. Li, H. Zhang, A. Wang, D. Jin, and S. Yang, "Effective production of biodiesel from nonedible oil using facile synthesis of imidazolium salts-based Brønsted-Lewis solid acid and co-solvent," Energy Conversion and Management, vol. 166, pp. 534-544, 2018.

[22] M. Sulewski and W. Urbaniak, "Utilization of biodiesel by-products," Czysta Energia, vol. 2011, no. 6, pp. 27-28, 2011.

[23] W. J. Choi, "Glycerol-based biorefinery for fuels and chemicals," Recent Patents on Biotechnology, vol. 2, no. 3, pp. 173-180, 2008.

[24] Y. Wu, X. Song, F. Cai, and G. Xiao, "Synthesis of glycerol carbonate from glycerol and diethyl carbonate over $\mathrm{Ce}-\mathrm{NiO}$ catalyst: the role of multiphase Ni," Journal of Alloys and Compounds, vol. 720, pp. 360-368, 2017.

[25] Y. Wu, X. Song, J. Zhang et al., "Synthesis of glycerol carbonate from glycerol and diethyl carbonate over $\mathrm{CeO}_{2}-\mathrm{CdO}$ catalyst: the role of $\mathrm{Ce}^{4+}$ doped into CdO lattice," Journal of the Taiwan Institute of Chemical Engineers, vol. 87, pp. 131-139, 2018.

[26] M. R. Monteiro, C. L. Kugelmeier, R. S. Pinheiro, M. O. Batalha, and A. da Silva César, "Glycerol from biodiesel production: technological paths for sustainability," Renewable and Sustainable Energy Reviews, vol. 88, pp. 109-122, 2018.

[27] A. Cornejo, I. Barrio, M. Campoy, J. Lázaro, and B. Navarrete, "Oxygenated fuel additives from glycerol valorization. Main production pathways and effects on fuel properties and engine performance: a critical review," Renewable and Sustainable Energy Reviews, vol. 79, pp. 1400-1413, 2017.

[28] N. T. Nguyen and Y. Demirel, "A novel biodiesel and glycerol carbonate production plant," International Journal of Chemical Reactor Engineering, vol. 9, no. 1, 2011.
[29] U. Nda-Umar, I. Ramli, Y. Taufiq-Yap, and E. Muhamad, "An overview of recent research in the conversion of glycerol into biofuels, fuel additives and other bio-based chemicals," Catalysts, vol. 9, no. 1, p. 15, 2019.

[30] A. Dibenedetto, A. Angelini, M. Aresta, J. Ethiraj, C. Fragale, and F. Nocito, "Converting wastes into added value products: from glycerol to glycerol carbonate, glycidol and epichlorohydrin using environmentally friendly synthetic routes," Tetrahedron, vol. 67, no. 6, pp. 1308-1313, 2011.

[31] A. Wang, H. Li, H. Pan et al., "Efficient and green production of biodiesel catalyzed by recyclable biomass-derived magnetic acids," Fuel Processing Technology, vol. 181, pp. 259-267, 2018.

[32] G. Rokicki, P. Rakoczy, P. Parzuchowski, and M. Sobiecki, "Hyperbranched aliphatic polyethers obtained from environmentally benign monomer: glycerol carbonate," Green Chemistry, vol. 7, no. 7, pp. 529-539, 2005.

[33] H. Pan, H. Li, H. Zhang, A. Wang, and S. Yang, "Acidic ionic liquid-functionalized mesoporous melamine-formaldehyde polymer as heterogeneous catalyst for biodiesel production," Fuel, vol. 239, pp. 886-895, 2019.

[34] J. Hu, Y. Gu, Z. Guan et al., "An efficient palladium catalyst system for the oxidative carbonylation of glycerol to glycerol carbonate," ChemSusChem, vol. 4, no. 12, pp. 1767-1772, 2011.

[35] J. Hu, J. Li, Y. Gu et al., "Oxidative carbonylation of glycerol to glycerol carbonate catalyzed by $\mathrm{PdCl}_{2}$ (phen)/KI," Applied Catalysis A: General, vol. 386, no. 1-2, pp. 188-193, 2010.

[36] J. George, Y. Patel, S. M. Pillai, and P. Munshi, "Methanol assisted selective formation of 1, 2-glycerol carbonate from glycerol and carbon dioxide using ${ }^{n} \mathrm{Bu}_{2} \mathrm{SnO}$ as a catalyst," Journal of Molecular Catalysis A: Chemical, vol. 304, no. 1-2, pp. 1-7, 2009.

[37] C. Vieville, J. Yoo, S. Pelet, and Z. Mouloungui, "Synthesis of glycerol carbonate by direct carbonatation of glycerol in supercritical $\mathrm{CO}_{2}$ in the presence of zeolites and ion exchange resins," Catalysis Letters, vol. 56, no. 4, pp. 245-247, 1998.

[38] Y. Hu, B. Zhou, and C. Wang, "Inert C-H bond transformations enabled by organometallic manganese catalysis," Accounts of Chemical Research, vol. 51, no. 3, pp. 816-827, 2018.

[39] J. He, H. Li, S. Saravanamurugan, and S. Yang, "Catalytic upgrading of biomass-derived sugars with acidic nanoporous materials: structural role in carbon-chain length variation," ChemSusChem, vol. 12, no. 2, pp. 347-378, 2019.

[40] A. Behr, J. Eilting, K. Irawadi, J. Leschinski, and F. Lindner, "Improved utilisation of renewable resources: new important derivatives of glycerol," Green Chemistry, vol. 10, no. 1, pp. 13-30, 2008.

[41] M. Pagliaro, R. Ciriminna, H. Kimura, M. Rossi, and C. Della Pina, "From glycerol to value-added products," Angewandte Chemie International Edition, vol. 46, no. 24, pp. 4434-4440, 2007.

[42] T. Sakakura, J. C. Choi, and H. Yasuda, "Transformation of carbon dioxide," Chemical Reviews, vol. 107, no. 6, pp. 23652387, 2007.

[43] J. H. Park, J. S. Choi, S. K. Woo et al., "Isolation and characterization of intermediate catalytic species in the $\mathrm{Zn}$ catalyzed glycerolysis of urea," Applied Catalysis A: General, vol. 433, pp. 35-40, 2012.

[44] T. W. Turney, A. Patti, W. Gates, U. Shaheen, and S. Kulasegaram, "Formation of glycerol carbonate from glycerol and urea catalysed by metal monoglycerolates," Green Chemistry, vol. 15, no. 7, pp. 1925-1931, 2013. 
[45] E. E. Oprescu, E. Stepan, P. Rosca, A. Radu, and C. E. Enascuta, "Synthesis of glycerol carbonate over hydrotalcite catalyst," Revista de Chimie, vol. 63, pp. 621-625, 2012.

[46] S. Fujita, Y. Yamanishi, and M. Arai, "Synthesis of glycerol carbonate from glycerol and urea using zinc-containing solid catalysts: a homogeneous reaction," Journal of Catalysis, vol. 297, pp. 137-141, 2013.

[47] M. S. Martin-González, M. A. García, I. Lorite et al., "A solidstate electrochemical reaction as the origin of magnetism at oxide nanoparticle interfaces," Journal of the Electrochemical Society, vol. 157, no. 3, pp. E31-E35, 2010.

[48] A. Brinkman, M. Huijben, M. van Zalk et al., "Magnetic effects at the interface between nonmagnetic oxides," Nature Materials, vol. 6, no. 7, pp. 493-496, 2007.

[49] F. Bruno, J. Garcia-Barriocanal, M. Torija et al., "Effects of interface states on the transport properties of all-oxide $\mathrm{La}_{0.8} \mathrm{Sr}_{0.2} \mathrm{CoO}_{3} / \mathrm{SrTi}_{0.99} \mathrm{Nb}_{0.01} \mathrm{O}_{3} p$ - $n$ heterojunctions," Applied Physics Letters, vol. 92, no. 8, p. 082106, 2008.

[50] A. Quesada, M. A. Garcia, M. Andrés et al., "Ferromagnetism in bulk Co-Zn-O," Journal of Applied Physics, vol. 100, no. 11, p. 113909, 2006.

[51] M. S. Martín-González, J. F. Fernández, F. Rubio-Marcos et al., "Insights into the room temperature magnetism of $\mathrm{ZnO} /$ $\mathrm{Co}_{3} \mathrm{O}_{4}$ mixtures," Journal of Applied Physics, vol. 103, no. 8, p. 083905, 2008.

[52] F. Rubio-Marcos, V. Calvino-Casilda, M. Banares, and J. Fernandez, "Novel hierarchical $\mathrm{Co}_{3} \mathrm{O}_{4} / \mathrm{ZnO}$ mixtures by dry nanodispersion and their catalytic application in the carbonylation of glycerol," Journal of Catalysis, vol. 275, no. 2, pp. 288-293, 2010.

[53] P. Zhang, L. Liu, M. Fan, Y. Dong, and P. Jiang, “The valueadded utilization of glycerol for the synthesis of glycerol carbonate catalyzed with a novel porous $\mathrm{ZnO}$ catalyst," RSC Advances, vol. 6, no. 80, pp. 76223-76230, 2016.

[54] Y. B. Ryu, J. S. Kim, K. H. Kim, Y. Kim, and M. S. Lee, "Synthesis of $\mathrm{Zn} / \mathrm{Al}$ mixed-oxide catalyst for carbonylation of glycerol with urea," Research on Chemical Intermediates, vol. 42, no. 1, pp. 83-93, 2016.

[55] H. Nguyen-Phu, C. Park, and E. W. Shin, "Dual catalysis over $\mathrm{ZnAl}$ mixed oxides in the glycerolysis of urea: homogeneous and heterogeneous reaction routes," Applied Catalysis A: General, vol. 552, pp. 1-10, 2018.

[56] H. Nguyen-Phu and E. W. Shin, "Investigating time-dependent $\mathrm{Zn}$ species over $\mathrm{Zn}$-based catalysts in glycerol carbonylation with urea and their roles in the reaction mechanism," Applied Catalysis A: General, vol. 561, pp. 28-40, 2018.

[57] H. Nguyen-Phu and E. W. Shin, "Disordered structure of $\mathrm{ZnAl}_{2} \mathrm{O}_{4}$ phase and the formation of a $\mathrm{Zn}$ NCO complex in $\mathrm{ZnAl}$ mixed oxide catalysts for glycerol carbonylation with urea," Journal of Catalysis, vol. 373, pp. 147-160, 2019.

[58] H. Li, X. Jiao, L. Li et al., "Synthesis of glycerol carbonate by direct carbonylation of glycerol with $\mathrm{CO}_{2}$ over solid catalysts derived from $\mathrm{Zn} / \mathrm{Al} / \mathrm{La}$ and $\mathrm{Zn} / \mathrm{Al} / \mathrm{La} / \mathrm{M}(\mathrm{M}=\mathrm{Li}, \mathrm{Mg}$, and $\mathrm{Zr})$ hydrotalcites," Catalysis Science \& Technology, vol. 5, no. 2, pp. 989-1005, 2015.

[59] F. Rubio-Marcos, V. Calvino-Casilda, M. A. Bañares, and J. F. Fernandez, "Control of the interphases formation degree in $\mathrm{Co}_{3} \mathrm{O}_{4} / \mathrm{ZnO}$ catalysts," ChemCatChem, vol. 5, no. 6, pp. 1431-1440, 2013.

[60] P. Manjunathan, R. Ravishankar, and G. V. Shanbhag, "Novel bifunctional $\mathrm{Zn}-\mathrm{Sn}$ composite oxide catalyst for the selective synthesis of glycerol carbonate by carbonylation of glycerol with urea," ChemCatChem, vol. 8, no. 3, pp. 631-639, 2016.

[61] X. Liu, H. Zhang, F. Chang, S. Huang, K. Yang, and S. Yang, "Catalytic transformations of organic compounds and biomass derivatives with functionalized metal-organic frameworks," Current Organic Chemistry, vol. 20, no. 7, pp. 761-776, 2016.

[62] Y. Lü, Y. Jiang, Q. Zhou et al., "Heterometallic metal-organic framework-templated synthesis of porous $\mathrm{Co}_{3} \mathrm{O}_{4} / \mathrm{ZnO}$ nanocage catalysts for the carbonylation of glycerol," Journal of Solid State Chemistry, vol. 256, pp. 93-100, 2017.

[63] S. Kondawar, A. Potdar, and C. Rode, "Solvent-free carbonylation of glycerol with urea using metal loaded MCM41 catalysts," RSC Advances, vol. 5, no. 21, pp. 16452-16460, 2015.

[64] S. Kondawar, R. Mane, A. Vasishta, S. More, S. Dhengale, and C. Rode, "Carbonylation of glycerol with urea to glycerol carbonate over supported Zn catalysts," Applied Petrochemical Research, vol. 7, no. 1, pp. 41-53, 2017.

[65] V.S. Marakatti and A. B. Halgeri, "Metal ion-exchanged zeolites as highly active solid acid catalysts for the green synthesis of glycerol carbonate from glycerol," RSC Advances, vol. 5, no. 19, pp. 14286-14293, 2015.

[66] K. Jagadeeswaraiah, C. R. Kumar, P. S. Prasad, and N. Lingaiah, "Incorporation of $\mathrm{Zn}^{2+}$ ions into the secondary structure of heteropoly tungstate: catalytic efficiency for synthesis of glycerol carbonate from glycerol and urea," Catalysis Science \& Technology, vol. 4, no. 9, pp. 2969-2977, 2014.

[67] J. Li and T. Wang, "Coupling reaction and azeotropic distillation for the synthesis of glycerol carbonate from glycerol and dimethyl carbonate," Chemical Engineering and Processing: Process Intensification, vol. 49, no. 5, pp. 530-535, 2010.

[68] M. J. Climent, A. Corma, P. De Frutos et al., "Chemicals from biomass: synthesis of glycerol carbonate by transesterification and carbonylation with urea with hydrotalcite catalysts. The role of acid-base pairs," Journal of Catalysis, vol. 269, no. 1, pp. 140-149, 2010.

[69] C. Buchaly, P. Kreis, and A. Górak, "Hybrid separation processes-Combination of reactive distillation with membrane separation," Chemical Engineering and Processing: Process Intensification, vol. 46, no. 9, pp. 790-799, 2007.

[70] N. Lertlukkanasuk, S. Phiyanalinmat, W. Kiatkittipong, A. Arpornwichanop, F. Aiouache, and S. Assabumrungrat, "Reactive distillation for synthesis of glycerol carbonate via glycerolysis of urea," Chemical Engineering and Processing: Process Intensification, vol. 70, pp. 103-109, 2013.

[71] J. D. Moseley and C. O. Kappe, "A critical assessment of the greenness and energy efficiency of microwave-assisted organic synthesis," Green Chemistry, vol. 13, no. 4, pp. 794-806, 2011.

[72] N. Kaur, "Applications of microwaves in the synthesis of polycyclic six-membered N, N-heterocycles," Synthetic Communications, vol. 45, no. 14, pp. 1599-1631, 2015.

[73] N. A. Khan and S. H. Jhung, "Synthesis of metal-organic frameworks (MOFs) with microwave or ultrasound: rapid reaction, phase-selectivity, and size reduction," Coordination Chemistry Reviews, vol. 285, pp. 11-23, 2015.

[74] M. G. Ma, J. F. Zhu, Y. J. Zhu, and R. C. Sun, "The microwaveassisted ionic-liquid method: a promising methodology in nanomaterials," Chemistry-An Asian Journal, vol. 9, no. 9, pp. 2378-2391, 2014. 
[75] D. D. Young, J. Nichols, R. M. Kelly, and A. Deiters, "Microwave activation of enzymatic catalysis," Journal of the American Chemical Society, vol. 130, no. 31, pp. 10048-10049, 2008.

[76] W. Xiao, X. Zhang, X. Wang, W. Niu, and L. Han, "Rapid liquefaction of corn stover with microwave heating," BioResources, vol. 10, no. 3, pp. 4038-4047, 2015.

[77] J. Tharun, G. Mathai, A. C. Kathalikkattil, R. Roshan, J. Y. Kwak, and D. W. Park, "Microwave-assisted synthesis of cyclic carbonates by a formic acid/KI catalytic system," Green Chemistry, vol. 15, no. 6, pp. 1673-1677, 2013.

[78] X. Yang, J. Wu, X. Mao, T. F. Jamison, and T. A. Hatton, "Microwave assisted synthesis of cyclic carbonates from olefins with sodium bicarbonates as the $\mathrm{C} 1$ source," Chemical Communications, vol. 50, no. 24, pp. 3245-3248, 2014.

[79] D. M. Pearson, N. R. Conley, and R. M. Waymouth, "Palladiumcatalyzed carbonylation of diols to cyclic carbonates," Advanced Synthesis \& Catalysis, vol. 353, no. 16, pp. 3007-3013, 2011.

[80] L. Liao, C. Zhang, and S. Gong, "Rapid synthesis of poly (trimethylene carbonate) by microwave-assisted ring-opening polymerization," European Polymer Journal, vol. 43, no. 10, pp. 4289-4296, 2007.

[81] L. Zhang, Z. Zhang, C. Wu et al., "Microwave assisted synthesis of glycerol carbonate from glycerol and urea," Pure and Applied Chemistry, vol. 90, no. 1, pp. 1-6, 2018.

[82] D. Singh, A. Ganesh, and S. Mahajani, "Heterogeneous catalysis for biodiesel synthesis and valorization of glycerol," Clean Technologies and Environmental Policy, vol. 17, no. 4, pp. 1103-1110, 2015.

[83] T. Lopez, P. Bosch, E. Ramos et al., "Synthesis and characterization of sol-gel hydrotalcites. Structure and texture," Langmuir, vol. 12, no. 1, pp. 189-192, 1996.

[84] T. Yamaguchi, Y. Wang, M. Komatsu, and M. Ookawa, "Preparation of new solid bases derived from supported metal nitrates and carbonates," Catalysis Surveys from Japan, vol. 5, no. 2, pp. 81-89, 2002.

[85] V. Montouillout, D. Massiot, A. Douy, and J. P. Coutures, "Characterization of $\mathrm{MgAl}_{2} \mathrm{O}_{4}$ precursor powders prepared by aqueous route," Journal of the American Ceramic Society, vol. 82, no. 12, pp. 3299-3304, 1999.

[86] A. G. Merzhanov, "The chemistry of self-propagating hightemperature synthesis," Journal of Materials Chemistry, vol. 14, no. 12, pp. 1779-1786, 2004.

[87] K. C. Patil, S. T. Aruna, and T. Mimani, "Combustion synthesis: an update," Current Opinion in Solid State and Materials Science, vol. 6, no. 6, pp. 507-512, 2002.

[88] K. Deshpande, A. Mukasyan, and A. Varma, "Direct synthesis of iron oxide nanopowders by the combustion approach: reaction mechanism and properties," Chemistry of Materials, vol. 16, no. 24, pp. 4896-4904, 2004.

[89] K. C. Patil, S. T. Aruna, and S. Ekambaram, "Combustion synthesis," Current Opinion in Solid State and Materials Science, vol. 2, no. 2, pp. 158-165, 1997.

[90] G. D. Yadav, N. P. Ajgaonkar, and A. Varma, "Preparation of highly superacidic sulfated zirconia via combustion synthesis and its application in Pechmann condensation of resorcinol with ethyl acetoacetate," Journal of Catalysis, vol. 292, pp. 99-110, 2012.

[91] G. P. Fernandes and G. D. Yadav, "Selective glycerolysis of urea to glycerol carbonate using combustion synthesized magnesium oxide as catalyst," Catalysis Today, vol. 309, pp. 153-160, 2018.
[92] A. S. K. Hashmi and G. J. Hutchings, "Gold catalysis," Angewandte Chemie International Edition, vol. 45, no. 47, pp. 7896-7936, 2006.

[93] F. Porta and L. Prati, "Selective oxidation of glycerol to sodium glycerate with gold-on-carbon catalyst: an insight into reaction selectivity," Journal of Catalysis, vol. 224, no. 2, pp. 397-403, 2004.

[94] N. Dimitratos, J. A. Lopez-Sanchez, D. Morgan, A. Carley, L. Prati, and G. J. Hutchings, "Solvent free liquid phase oxidation of benzyl alcohol using Au supported catalysts prepared using a sol immobilization technique," Catalysis Today, vol. 122, no. 3-4, pp. 317-324, 2007.

[95] C. Hammond, J. A. Lopez-Sanchez, M. H. Ab Rahim et al., "Synthesis of glycerol carbonate from glycerol and urea with gold-based catalysts," Dalton Transactions, vol. 40, no. 15, pp. 3927-3937, 2011.

[96] M. H. Ab Rahim, Q. He, J. A. Lopez-Sanchez et al., "Gold, palladium and gold-palladium supported nanoparticles for the synthesis of glycerol carbonate from glycerol and urea," Catalysis Science \& Technology, vol. 2, no. 9, pp. 1914-1924, 2012.

[97] Y. Sun, X. Tong, Z. Wu, J. Liu, Y. Yan, and S. Xue, "A sustainable preparation of glycerol carbonate from glycerol and urea catalyzed by hydrotalcite-like solid catalysts," Energy Technology, vol. 2, no. 3, pp. 263-268, 2014.

[98] D. Wang, X. Zhang, X. Cong, S. Liu, and D. Zhou, "Influence of $\mathrm{Zr}$ on the performance of $\mathrm{Mg}$ - $\mathrm{Al}$ catalysts via hydrotalcitelike precursors for the synthesis of glycerol carbonate from urea and glycerol," Applied Catalysis A: General, vol. 555, pp. 36-46, 2018.

[99] K. Jagadeeswaraiah, C. R. Kumar, P. S. Prasad, S. Loridant, and N. Lingaiah, "Synthesis of glycerol carbonate from glycerol and urea over tin-tungsten mixed oxide catalysts," Applied Catalysis A: General, vol. 469, pp. 165-172, 2014.

[100] M. Srinivas, G. Raveendra, G. Parameswaram, P. S. Prasad, S. Loridant, and N. Lingaiah, "Understanding the surface and structural characteristics of tungsten oxide supported on tin oxide catalysts for the conversion of glycerol," Journal of Chemical Sciences, vol. 127, no. 5, pp. 897-908, 2015.

[101] K. Jagadeeswaraiah, C. R. Kumar, A. Rajashekar, A. Srivani, and N. Lingaiah, "The role of tungsten oxide species supported on titania catalysts for the synthesis of glycerol carbonate from glycerol and urea," Catalysis Letters, vol. 146, no. 3, pp. 692-700, 2016.

[102] N. Narkhede and A. Patel, "Facile synthesis of glycerol carbonate via glycerolysis of urea catalysed by silicotungstates impregnated into MCM-41," RSC Advances, vol. 5, no. 65, pp. 52801-52808, 2015.

[103] N. Narkhede and A. Patel, "Sustainable valorisation of glycerol via acetalization as well as carboxylation reactions over silicotungstates anchored to zeolite $\mathrm{H} \beta$," Applied Catalysis A: General, vol. 515, pp. 154-163, 2016.

[104] I. V. Kozhevnikov, "Catalysis by heteropoly acids and multicomponent polyoxometalates in liquid-phase reactions," Chemical Reviews, vol. 98, no. 1, pp. 171-198, 1998.

[105] N. Mizuno and M. Misono, "Heterogeneous catalysis," Chemical Reviews, vol. 98, no. 1, pp. 199-218, 1998.

[106] E. F. Kozhevnikova, E. G. Derouane, and I. V. Kozhevnikov, "Heteropoly acid as a novel efficient catalyst for Fries rearrangement," Chemical Communications, vol. 11, pp. 1178-1179, 2002.

[107] A. Corma, A. Martınez, and C. Martınez, "Acidic Cs ${ }^{+}, \mathrm{NH}_{4}^{+}$, and $\mathrm{K}^{+}$salts of 12-tungstophosphoric acid as solid catalysts for 
isobutane/2-butene alkylation," Journal of Catalysis, vol. 164, no. 2, pp. 422-432, 1996.

[108] C. R. Kumar, K. V. Rao, P. S. Prasad, and N. Lingaiah, “Tin exchanged heteropoly tungstate: an efficient catalyst for benzylation of arenes with benzyl alcohol," Journal of Molecular Catalysis A: Chemical, vol. 337, no. 1-2, pp. 17-24, 2011.

[109] C. R. Kumar, P. S. Prasad, and N. Lingaiah, "Aluminium exchanged heteropoly tungstate supported on titania catalysts: the generation of Lewis acidity and its role for benzylation reaction," Journal of Molecular Catalysis A: Chemical, vol. 350, no. 1-2, pp. 83-90, 2011.

[110] K. M. Reddy, N. S. Babu, P. S. Prasad, and N. Lingaiah, "Aluminium-exchanged tungstophosphoric acid: an efficient catalyst for intermolecular hydroarylation of vinyl arenes," Catalysis Communications, vol. 9, no. 15, pp. 2525-2531, 2008.

[111] C. R. Kumar, K. Jagadeeswaraiah, P. S. Prasad, and N. Lingaiah, "Samarium-exchanged heteropoly tungstate: an efficient solid acid catalyst for the synthesis of glycerol carbonate from glycerol and benzylation of anisole," ChemCatChem, vol. 4, no. 9, pp. 1360-1367, 2012.

[112] A. Srikanth, B. Viswanadham, V. P. Kumar, N. R. Anipindi, and K. V. Chary, "Synthesis and characterization of Csexchanged heteropolyacid catalysts functionalized with $\mathrm{Sn}$ for carbonolysis of glycerol to glycerol carbonate," Applied Petrochemical Research, vol. 6, no. 2, pp. 145-153, 2016.

[113] M. S. Babu, A. Srivani, G. Parameswaram, G. Veerabhadram, and N. Lingaiah, "Understanding the role of tantalum in heteropoly tungstate catalysts for the synthesis of glycerol carbonate from glycerol and urea," Catalysis Letters, vol. 145, no. 9, pp. 1784-1791, 2015.

[114] J. Chen, C. Wang, B. Dong et al., "Ionic liquids as ecofriendly catalysts for converting glycerol and urea into high value-added glycerol carbonate," Chinese Journal of Catalysis, vol. 36, no. 3, pp. 336-343, 2015.

[115] H. Zhang, H. Li, H. Pan et al., "Efficient production of biodiesel with promising fuel properties from Koelreuteria integrifoliola oil using a magnetically recyclable acidic ionic liquid," Energy Conversion and Management, vol. 138, pp. 45-53, 2017.

[116] M. Valkenberg, C. DeCastro, and W. Hölderich, "Immobilisation of ionic liquids on solid supports," Green Chemistry, vol. 4, no. 2, pp. 88-93, 2002.

[117] C. P. Mehnert, R. A. Cook, N. C. Dispenziere, and M. Afeworki, "Supported ionic liquid catalysis-A new concept for homogeneous hydroformylation catalysis," Journal of the American Chemical Society, vol. 124, no. 44, pp. 1293212933, 2002.

[118] D. W. Kim, M. S. Park, M. Selvaraj, G. A. Park, S. D. Lee, and D. W. Park, "Catalytic performance of polymer-supported ionic liquids in the synthesis of glycerol carbonate from glycerol and urea," Research on Chemical Intermediates, vol. 37, no. 9, pp. 1305-1312, 2011.

[119] D. W. Kim, M. J. Kim, K. Roshith, M. I. Kim, J. Y. Kwak, and D. W. Park, "Comparative catalytic activity of supported $\mathrm{ZnBr}_{2}$-containing ionic liquid catalysts for preparation of glycerol carbonate by glycerolysis of urea," Korean Journal of Chemical Engineering, vol. 31, no. 6, pp. 972-980, 2014.

[120] S. D. Lee, M. S. Park, D. W. Kim, I. Kim, and D. W. Park, "Catalytic performance of ion-exchanged montmorillonite with quaternary ammonium salts for the glycerolysis of urea," Catalysis Today, vol. 232, pp. 127-133, 2014.
[121] D. W. Kim, K. A. Park, M. J. Kim, D. H. Kang, J. G. Yang, and D. W. Park, "Synthesis of glycerol carbonate from urea and glycerol using polymer-supported metal containing ionic liquid catalysts," Applied Catalysis A: General, vol. 473, pp. 31-40, 2014.

[122] R. I. D. Suyatmo, H. Sulistyo, and W. B. Sediawan, "The synthesis of glycerol carbonate from biodiesel by product glycerol and urea over amberlyst 15," Jurnal Bahan Alam Terbarukan, vol. 6, no. 2, pp. 143-149, 2017.

[123] D. Wang, X. Zhang, C. Liu, and T. Cheng, "Synthesis of glycerol carbonate from glycerol and urea over lanthanum compounds," Reaction Kinetics, Mechanisms and Catalysis, vol. 115, no. 2, pp. 597-609, 2015.

[124] L. Wang, Y. Ma, Y. Wang, S. Liu, and Y. Deng, "Efficient synthesis of glycerol carbonate from glycerol and urea with lanthanum oxide as a solid base catalyst," Catalysis Communications, vol. 12, no. 15, pp. 1458-1462, 2011.

[125] J. Zhang and D. He, "Lanthanum-based mixed oxides for the synthesis of glycerol carbonate from glycerol and urea," Reaction Kinetics, Mechanisms and Catalysis, vol. 113, no. 2, pp. 375-392, 2014.

[126] W. Luo, L. Sun, Y. Yang et al., "Cu-Mn composite oxides: highly efficient and reusable acid-base catalysts for the carbonylation reaction of glycerol with urea," Catalysis Science \& Technology, vol. 8, no. 24, pp. 6468-6477, 2018.

[127] M. Aresta, A. Dibenedetto, F. Nocito, and C. Ferragina, "Valorization of bio-glycerol: new catalytic materials for the synthesis of glycerol carbonate via glycerolysis of urea," Journal of Catalysis, vol. 268, no. 1, pp. 106-114, 2009.

[128] V. P. Indran, N. A. S. Zuhaimi, M. A. Deraman et al., "An accelerated route of glycerol carbonate formation from glycerol using waste boiler ash as catalyst," RSC Advances, vol. 4, no. 48, pp. 25257-25267, 2014.

[129] N. A. S. Zuhaimi, V. P. Indran, M. A. Deraman et al., "Reusable gypsum based catalyst for synthesis of glycerol carbonate from glycerol and urea," Applied Catalysis A: General, vol. 502, pp. 312-319, 2015. 